\title{
Environmental Regulation and Location of Industrialized Agricultural Production in Europe
}

\author{
Abay Mulatu \\ Economics Division, London Metropolitan Business School, London Metropolitan University, Old \\ Castle Street, London, E1 7PF, United Kingdom \\ Ada Wossink \\ Economics, School of Social Sciences, University of Manchester, Oxford Road, Manchester M13 \\ 9PL, United Kingdom
}

\begin{abstract}
This paper analyses empirically the extent to which environmental regulation influences production location in the pig industry. The analysis is based on a general empirical location model that captures interactions between region and sector characteristics in determining production location, and data on pig production in 43 European regions. We find that while environmental regulation may not have a measurable effect on the EU pig industry location per se, it is a strong influence on the sectoral composition of the industry. Relatively highly-polluting sectors of the pig industry are attracted to relatively lax jurisdictions which become pollution-havens (hotspots of hog waste).
\end{abstract}

The authors are, respectively, Senior Lecturer (Associate Professor) in Economics at London Metropolitan University, London, UK, and Professor of Environmental Economics at the University of Manchester, Manchester, UK. Financial support from the Leverhulme Trust under grant RF-2011-550 is gratefully acknowledged. We also kindly acknowledge the input, data and conceptual support from Robert Hoste (LEI-DLO, The Hague), The Netherlands. We wish to thank Ludwig Lauwers, Alfons Weersink, Tom Vukina, and participants of the 2nd Agrimba Conference in Wageningen, The Netherlands and of the $19^{\text {th }}$ Annual Conference of the European Association of Environmental and Resource Economists in Prague, the Czech Republic for very helpful comments. The usual disclaimer applies. 


\section{INTRODUCTION}

Industrialized livestock systems are becoming the standard in meat production the world over. Especially the pig and poultry industries experienced changing market structures and rapid growth in the 1980s and 1990s. Feed is sourced through international markets and production has become clustered in areas where input costs are relatively low and access to international markets are well developed. The distancing of animal husbandry from feed-crops has led to a system where there is no longer a direct coupling to a local land base through a feed-crop-manure system (Innes 2000; Naylor et al. 2005). In combination with the large-scale units favoured by the new supply chains, this has led to vast amounts of animal waste that cannot be processed by the local resource base.

Alongside concentration, increasing specialization within an industry appears to be a characteristic feature of the livestock system. Pig husbandry in particular has evolved towards specialized units that focus on parts of the animal's lifecycle: sows (with piglets), weaned pigs and pigs for fattening (see e.g. Kliebenstein and Lawrence 1995). Specialized farrowing-nursery farms and finishing (growing pigs or 'hogs') operations are far more common in Europe than operations that cover the complete lifecycle. Farms that specialize in rearing juvenile pigs during the first weeks after weaning are a recent development in Europe. ${ }^{1}$ The production system thus consists of multiple enterprises with the pigs transported from the farrowing-nursery units to the finishing units.

Spatial concentration of pig production is generally a serious environmental concern (Innes 2000). However it is not only concentration but also specialization within the pig industry that has environmental implications. Specialization is increasingly regionally distinct and emissions differ substantially by animal category. ${ }^{2}$ In most EU countries, pigs for fattening account for the largest category among total pig stocks as would be expected given the animal's lifecycle (see Table 1). ${ }^{3}$ The two producing countries that do not follow this pattern are Denmark and the Netherlands where the largest category in 2002 was piglets (Table 1). Dutch and Danish feeder pigs are to a large extent exported to be finished abroad. In 2005, for example, $90 \%$ of the Danish feeder pigs were exported to Germany and the rest to Italy and Poland. The Netherlands had a more varied export portfolio: $51 \%$ to Germany (2.053.000); Spain (602.000); Italy (230.0000); Belgium/Luxemburg (237.000); Poland (171.000) and Hungary (151.000) (de Winter 2008). 
Pig production is concentrated in a few countries with over two thirds of the total inventory found in Germany, Spain, Poland, France, Denmark and the Netherlands (Table 1). Data at regional level - NUTS1 (Nomenclature of territorial units for statistics) - is more informative than national figures as a mean of identifying hotspots of spatial concentration (Table 2). It follows that a major production basin extends from Denmark (DK), through western-Germany (DE9 and DEA) to the south of the Netherlands (NL4). Important other regions are found in Spain (ES2 and ES4-5); in France (Brittany, FR5), and in central Poland (PL4). At NUTS1 level there is again a clear difference in the composition of the pig inventory in the various regions (see Table 2).

$<$ Tables 1 and 2 about here $>$

Thus the spatial structure of pig production in the EU is increasingly characterized by geographic specialization in the stages of the production cycle in addition to geographic concentration. This transformation has accelerated in the last ten years. This raises the question: what determines such specialization patterns in the industry and more generally, the location of pig production? In general it is the interaction of public policy, technological advances, market forces and social factors that shapes spatial changes in animal production (Abdalla, Lanyon and Hallberg 1995). It has been suggested that the main driving forces for the development in the EU are higher prices of pigs abroad and increased differences in traditional production costs and environmental compliance costs (Larue, Abildtrup and Schmitt 2011).

This paper examines the extent to which environmental regulations influence the location of production of pig production in Europe and how this compares with other determinants of location. Some countries in Europe have experienced high animal densities for some time and introduced national regulation in the late 1980s (e.g., Germany and Denmark). Nutrients in manure, principally nitrogen and phosphorus, are a significant component of potential pollution from agriculture to surface and ground water. The soil nitrogen balance indicator is commonly used to reveal the risks (OECD, 2013). This indicator methodology employs basic data (such as crop area, crop production, livestock numbers etc.) and coefficients (for $\mathrm{N}$-emission by animal type and $\mathrm{N}$-uptake by crop) to convert this data into nitrogen content. There is a strong correlation of N-surplus per hectare and livestock density (see 
e.g., Oenema, 2004). Surplus assessments in the 1990s by the EU's statistical office EUROSTAT indicated that for approximately $25 \%$ of the agricultural land in the EU the nitrate levels were likely over $50 \mathrm{mg} / \mathrm{l}$ (EU drinking water standard). High nitrogen surpluses (150 kg/ha/yr and more) occur especially in EU-regions with intensive animal production (Schleef and Kleinhanss 1997).

From the 1990s onwards, EU environmental policies have started to overrule national measures with the EU Nitrate Directive which was issued in 1991. The Directive provides guidance on how EU countries should deal with the nitrate problem specifically from agricultural sources. The Directive requires monitoring of all surface waters and ground waters for nitrate pollution against a maximum limit of $50 \mathrm{mg}$ NO3- per liter. Where this level of pollution is reached, land draining into the affected waters must be designated as Nitrate Vulnerable Zones (NVZs). Codes of Good Agricultural Practice must be elaborated and an Action Plan needs to be developed which makes these codes mandatory in the NVZs and puts into effects further measures aimed at manure management (e.g., storage capacity, restrictions on period of application, record keeping). Key element of the Directive is that the application of animal waste should not exceed $170 \mathrm{~kg}$ of nitrogen per ha/yr in the vulnerable zones. The Nitrates Directive allows for the possibility of derogation with respect to this maximum amount providing it is demonstrated that the directive's objectives can still be achieved because of advantageous agronomic and climatic conditions. The timetable for the implementation states that this Directive was to be implemented by 2003. Because of the EU's subsidiarity principle, implementation of EU Directives is not the task of the EU; rather this is done at the national, regional or local level (see e.g. Oenema 2004). The implementation at the lower level should respect the general framework but usually the regional implementation gives the regulations a local 'colour', addressing the regional specifics (Jongeneel et al. 2007, p. 22). This is shown for example by the approach countries have taken regarding the designation of the NVZs. The whole country was termed a $\mathrm{NVZ}$ in several countries where the responsibility with respect to water quality lies with the central government (e.g., Denmark, Finland, Germany and the Netherlands). In general transferring the Nitrate Directive into national law has been difficult in countries that have a number of autonomous regional authorities (e.g. Italy, Belgium and Spain) or that have (had) an uneven distribution of animal numbers within their borders. In addition, countries are on different trajectories because of the significant enlargement of the EU over time. ${ }^{4}$ The goals of the policy can also be different. Most countries have 
chosen nitrogen based systems because of the EU Nitrate Directive but others use systems based on both nitrogen and phosphorus emissions (De Clercq 2001). There is also considerable variation in the rigour of monitoring and control of implemented measures (Jongeneel et al 2007). Consequently there are large differences in the design, implementation and stringency of environmental regulations related to animal agriculture within the EU (European Commission 2002; Oenema 2004).

Producers may react to existing or impending regulation by exiting the industry or by changing the location of production. By moving (part of) production (most likely the 'dirtier' bits) to a different EU region a producer might mitigate or avoid the cost of domestic regulations, but adding new capacity at the same site might enable economies of scale and improvements in technical performance that offset additional costs of compliance.

The general question of the link between environmental standards and the location of production is a hotly debated issue addressed in what has come to be known as the Pollution Haven Hypothesis (PHH) literature. This hypothesis contends that changes in environmental standards results in a relocation of dirty goods production from jurisdictions with stringent environmental regulation to those with lax environmental regulation creating geographic hot spots with relatively high concentrations of polluters (Levinson and Taylor 2008). Therefore, if true, the PHH has an important implication for EU environmental policy, namely that further harmonization of environmental regulation across EU might be needed to undermine the emergence of pollution havens.

Against the background of differences in stringency of environmental regulation and interest in how such regulations affect (the location of) production and the associated pollution, this paper tests the PPH as an explanation for the significant differences in regional production shares in European pig production. In our empirical analysis we distinguish between the different sectors within the pig industry to reflect the specialization in the different stages of the production cycle.

There is a rather limited empirical research on the PHH related to the livestock sector, and it has largely been confined to North America, mainly the US. ${ }^{5}$ The typical methodology used in the literature (Metcalfe 2001; Roe, Irwin and Sharp 2002; Isik 2004; Herath, Weersink and Carpentier 2005a, 2005b; Weersink and Eveland 2006) is some form of a spatial lag or supply model where environmental regulation and other traditional location factors explain a region's share of the aggregate inventory of the animal industry. 
Sneeringer (2009) uses differences-in-differences and spline models which is supposed to circumvent the omitted variables and endogeneity caveats in the previous literature. Finally, Sneeringer and Key (2011) employ a regression discontinuity framework to explicitly test for the impact of size-based regulation on regulation avoidance behaviour of firms. To the best of our knowledge, there are only two econometric studies that have investigated the issue of location choice of industrialized animal agriculture in Europe. Larue, Abildtrup and Schmitt (2011) examine the forces of agglomeration and dispersion in the pig industry using municipal level data in Denmark. Gaigné et al. (2012) present a similar study of French cantons (US equivalent of counties) investigating whether land limitations driven by regulations on manure application are any influence on the location of pig production, in particular whether such regulations lead to agglomeration or dispersion of production. While the particular emphasis and the findings in the extant literature are varied and hence any sweeping generalization would be unwarranted, it is safe to say that the results on the PHH are mixed (Table A.1 in the Appendix presents a summary of the existing literature).

This study differs from the existing literature in one major respect. Our analysis explicitly acknowledges the prevailing specialized operations within the pig industry. Thus, the main unit of analysis in our study is sector within the pig industry rather than the pig industry as a whole. The significance of this is that we allow for the fact that environmental regulation might affect the different sectors within the industry differently owing to the differential pollution-intensity between the sectors. Also related to this point, it can be argued that while environmental regulation may not impact on the industry as a whole, it can affect the composition of the sectors within the pig industry.

We intend to make four contributions. First, our study complements the fledgling literature on the PHH in the context of animal production by focussing on specific stages of the pig's lifecycle which has led to sectors within the pig industry, and thereby avoiding the potential danger of drawing inaccurate inferences due to pooling sectors that are in fact heterogeneous ( $c f$. Jeppesen, List and Folmer 2002). In fact, there is some recognition of this heterogeneity in the literature. For example, in their analysis of the spatial patterns of aggregate pig inventory in the US, Roe, Irwin and Sharp (2002, p. 264) include the variable share of sow in total pig inventory by arguing "[A]s farms have begun to specialize in either the breading or finishing segments of hog production, each segment may follow different spatial patterns." 
Second, while analysis has been conducted on changes in country-level livestock inventories, no work has been done to explain the spatial patterns of the pig industry across the EU. Thus our study complements the two single-country studies of the EU pig industry by drawing data from a cross-section of EU countries and by analysing whether and how the nature of the geographic concentration varies among regions. Also, unlike these two EU studies which mainly focus on forces of agglomeration and dispersion we examine the location of pig production as such and specially the possible impact of environmental regulations on sectoral composition of the pig industry.

Third, unlike much of the literature excepting Gaigné et al. (2012) we address the potential econometric problem associated with endogeneity of environmental regulation stringency.

Fourth, our findings have policy implications. The results of our study suggest that while environmental regulation in Europe may not have a measurable effect on the location of the pig industry per se, it is indeed a strong influence on the sectoral composition of the industry. These results are confirmed for different intensity measures (head count, weight gained and value of production). Relatively lax environmental standards attract relatively highly polluting sectors of the pig industry - creating pollution havens - and lead to long-distance live animal transport which has an environmental impact of a different kind as well as animal welfare effects.

The remainder of the paper is organised as follows. In the next section we present a descriptive material on the geographic distribution of the pig industry in the EU. In the third section we present our econometric methodology. The fourth section describes the main data used in the econometric analysis. The fifth section presents and discusses the results of our econometric estimation. The final section concludes the paper and elaborates on the implications of our findings for policy and for further research on the PHH in the context of commercialised agriculture.

\section{GEOGRAPHIC DISTRIBUTION OF THE PIG INDUSTRY IN THE EU}

As pointed out above, the European pig industry has for some time been undergoing changes in its structure, namely in terms of concentration and specialization. Our econometric analysis in the next section aims at investigating the potential driving forces, specially the role of environmental regulations. But before that we evaluate in this section the extent of the claimed specialization in 
the pig sector using data on the 43 NUTS1 regions of the six largest pig producers in the EU (Table 2). We consider standard measures of specialization and concentration and their changes over time. How specialized is a certain region? Consider the Krugman's specialization index (Krugman 1991):

$$
R_{i}(t)=\sum_{k}\left|E_{i}^{k}(t)-E_{i}^{-k}(t)\right|, \quad \quad R_{i} \in[0,2]
$$

where $E_{i}^{k}$ is the share of category $k$ in the total pig inventory of region $i$ and $E_{i}^{-k}$ is the share of the same category in the pig inventory of all other regions. The absolute value of the difference between these shares gives us a measure of the difference between the pig structure of region $i$ and all other regions. If the index has a value of two then the region is completely specialized, i.e. has no sectors in common with the rest, while if it is zero the region is completely similar to the rest of regions. ${ }^{6}$ As shown in Table 3 the average index has shown a modest change over time: from 0.304 in 2000 to about 0.306 in 2007 and a slight jump to 0.354 in 2008 .

\section{$<$ Table 3 about here $>$}

The extent of specialization indicated by these indices in 2000 and 2008 are respectively $15 \%$ and $18 \%$ - of complete specialization where a region has no sectors in common with the remaining regions. These levels of specialization are comparable with that of the manufacturing sector in EU of about $17 \%$ in 1970 s and $19 \%$ in the 1990 s. $^{7}$ The higher outcome of $18 \%$ for 2008 can be attributed to high feed prices that forced the most inefficient farmers to quit. As a result of shrinking production and inelastic demand, prices for slaughter hogs increased to the highest level in seven years. With feed prices reverting to more normal levels, profitability in fattening improved again in the second half of the year. These developments enhanced the ongoing specialization process as is shown by the jump in the specialization index for 2008 .

In contrast to the limited change in the average specialisation index there is quite a variation in the specialization indices across regions and for individual regions over time. The highest indices (above 0.4 in 2008) are those for DEC-Saarland, DE7-Hessen, DE9-Niedersachsen, DEA-Nordrhein-Westfalen, DEF-Schleswig-Holstein, ES4-Centro, ES6-Sur, FR1-Île de France and NL2-Oost Nederland. Some 
have shown quite a lot of change over time. FR7-Centre-Est, FR1-Île de France, DED-Sachsen and the four Dutch regions (Noord-Nederland, Oost- Nederland, West-Nederland, and Zuid-Nederland) saw their indices rise between 2000 and 2008 by over 40\%; whereas ES5-Este and DEG-Thüringen have become less specialized, a decline of the index by $10 \%$ and $17 \%$, respectively.

How concentrated or localised is an industry as a whole or a particular sector? The starting point here is the location coefficient: the share of region $i$ in the total inventory of animal category $k$ at time $t$ that is $s_{i, k}$ defined as:

$$
s_{i k}(t)=z_{i, k}(t) / \sum_{i} z_{i, k}(t)
$$

where $z_{i, k}$ measures the size of category $k$ in region $i$. We can then construct a simple index of concentration (Overman, Redding and Venables. 2003):

$$
L_{k}(t)=\sum_{i^{\prime}} \mid s_{i k}(t)-\text { area }_{i} \mid, \quad \quad L_{k} \in[0,2]
$$

where 'area' represents a region's area as a share of total land area. The rationale for including 'area' here is to control for size. This index has a maximum of two in the case of complete localization of a category in one region and a minimum of zero in the case of complete similarity, i.e. a category is completely dispersed across regions. The concentration index and the specialization index are complementary because while the former provides data on the pattern of each category the latter tells us the pattern of regions' structure of the pig industry. As regions become specialized you would expect at least some of the sectors to become concentrated.

Table 4 shows that there is considerable concentration in each category. The indexes range from 0.649 (for sows in 2002) to 0.74 (for weaners in 2008). The extent of concentration indicated by these indexes is, respectively, $32 \%$ and $37 \%$ - of complete localization where one category is concentrated in just one region. Overall, weaners are slightly more concentrated than growing pigs which in turn are more concentrated than sows. Thus the regional data confirm that pig production is moving towards regional specialisation focusing on breeding, rearing or fattening. In contrast, the average concentration index shows slight changes over time without a clear pattern mirroring the evolution of the specialization index 
discussed above. It follows that as regions begin to specialize in a segment of pig production, each segment will follow a different spatial pattern. These spatial patterns in turns are crucial, particularly for the purposes of gauging environmental consequences of distribution because segments differ in emission per animal place per year (see Roe, Irwin and Sharp 2002). A concentration index based on total inventories will fail to show this effect.

\section{$<$ Table 4 about here $>$}

It has to be noted that the sample countries under discussion (with a possible exception of Poland) have been well integrated economies for decades and one should not expect any sharp changes in specialization and concentration over our sample period of 2000-2008. So the changes in the calculated regional and concentration indexes are rather remarkable and lend support to the hypothesis of recent developments of differential environmental compliance cost across countries. In general the underlying reasons for regional specialization are to be found in the characteristics of regions and sectors and in the interactions of these characteristics. Our econometric analysis in the next section will examine these factors.

\section{ECONOMETRIC ANALYSIS OF THE LOCATION OF PIG PRODUCTION}

Our aim is to investigate the relevance of various factors in the location of industrialized animal agriculture. In particular, we want to know why some regions attract a high share of a certain category of the pig sector, while other regions have a much lower share. Formally, we investigate the determinants of the localization variable, $s_{i, k}$ we defined in the previous section as $s_{i k}=z_{i, k} / \sum z_{i, k}$ where $z_{i, k}$ measures the size of category $k$ in region $i$.

We adopt an empirical model similar to those of Midelfart-Knarvik et al. (2000), Crafts and Mulatu (2005), Mulatu et al. (2010) and Gerlagh and Mathys (2011). The major theme in these models is that the location of economic activity is determined by the interaction of region characteristics with the corresponding sector attributes. Regions are heterogeneous in various aspects such as endowments of natural resource and stringency of environmental regulation. Similarly, sectors differ in their various attributes such as the intensity of use of production factors like labor and the extent of pollution intensity. 
So if a regional characteristics $x^{j}$ matters for location, every sector would want to locate in a region that is rich in $x^{j}$ but a region cannot accommodate all sectors in unlimited numbers. In equilibrium we expect that sectors that highly value that region characteristic, i.e. those sectors with large $y^{j}$ will gravitate towards that region. All else equal, a labor intensive sector will tend to locate in a region with abundant labor, while pollution intensive sectors will be attracted to regions with a relatively lax environmental regulation. In the context of the $\mathrm{PHH}$ literature, the relevant empirical question is how strong is the interaction between environmental regulation and pollution intensity, relative to the interaction between other region and sector characteristics.

The region characteristics (together with the corresponding sector attributes) can be derived from Heckscher-Ohlin type comparative advantage arguments based on the role of factor endowments and/ or from New Economic Geography that stresses the importance of market access. Accordingly we specify our econometric model as:

$$
\ln s_{i, k, t}=\sum_{j} \beta^{j} x_{i, t}^{j} y_{k, t}^{j}+\theta_{i}+\delta_{k}+\tau_{t}+\varepsilon_{i, k, t}
$$

where $x$ is a vector of regional characteristics and $y$ is a vector of associated sector attributes. We consider the following four pairs of region characteristics and sector attributes: environmental regulation laxity and pollution intensity, feedstuff availability and feedstuff intensity, labor availability and labor intensity, and market potential and scale economies. Compliance to environmental regulations has become a major component of production cost, particularly to those sectors that are relatively more pollutionintensive. If land is located within a Nitrate Vulnerable Zone (part of the implementation of the EU Nitrate Directive), the farmer must comply with restrictions on the maximum amount of nitrogen that can be applied per ha and year. There are also restrictions on the period of spreading. In addition there has to be sufficient storage capacity (or alternative arrangements) to cater for the closed period. These restrictions mean that manure disposal becomes costly in regions with high livestock densities in particular. But several countries faced difficulties and delayed application into national regulations of the Nitrate Directive for many years. In countries with layered governance structures the national government 
delegated discretion to lower levels, i.e. regional authorities. For example, Italy chose to apply the Directive by designing vulnerable zones in each of its 20 regions. Whereas this process started in 1999 it was not till 2006 that the national decree regulating the zones and providing rules for manure and slurry spreading activities was approved. In the absence of a final decree a series of requirements farmers had to fulfil in order to comply with the nitrate directive were drafted. Since these were not yet backed by formal national law an Italian farmer in violation could be sanctioned by a reduction of the direct EU payments he was entitled to but no further legal action was possible (Jongeneel et al. 2007). Several other countries applied for derogation for a higher maximum allowance of nitrogen per ha; in general for crops with a higher nutrient uptake and a longer growing season (see Van der Straeten et al 2009). The EU started infringement procedures because of the lack of progress in specific countries; this related to the implementation of the Directive overall for Belgium and to parts of it for Spain, Italy, Portugal and the United Kingdom (COM 2007). The lack of compliance, delay and requests for derogation did not preclude other countries to integrate the Directive into their legal framework. Thus the manure-land limiting regulation is differently implemented and enforced in different countries. As a consequence significant differences developed in stringency (Jongeneel et al 2007). So a farmer in a country with stringent regulation, ceteris paribus, is less likely to specialize in a finishing-pig operation because it involves more waste.

The cost of primary pig production consists of feed costs, labor costs and interest and depreciation with differences in total cost composition by pig sector. For finishing pigs feed is considered the most important cost category (Nguyen et al. 2003). Availability of feedstuff has thus differing importance for the sectors within the pig industry. Feed cost can further differ by region depending on feed efficiency and feed prices.

The literature emphasises the importance of the quality and availability of local labor for efficient operation of the US pig industry and the regional variation in this factor (Roe, Irwin and Sharp 2002; Isik 2004). In EU pig industry too, there is substantial range in labor costs across regions which reflect not only variations in average wage rates but also national differences in social security payments made by employers as well as differences in the relative usage of unskilled labour (Fowler 2007). Labor input use is also known to differ across the sectors in the pig industry - farrowing operations, for example, 
are more labor intensive (Roe, Irwin and Sharp 2002, p. 275). Availability of labor would therefore be another region characteristic with a potentially differing importance for the sectors within the pig industry. Quality of labor in the sense of knowledge and skills, rather than education, is important in all the three sectors of the pig industry. The possible regional variation in such quality can be captured by the region fixed effects discussed below.

Another major driver of the pig industry in several EU regions has been domestic demand. For example in Spain, annual per capita pork consumption doubled between 1985 and 2002 and in 2003, Spaniards ranked as the world's second-largest consumers of pig meat on a per capita basis behind Austrians. This noticeable increase can be largely attributed to the substantial growth in per capita income after Spain joined the EU and a preference for (more expensive) cured meat products (Lence 2007).

The first three pairs, those related to environment, labor and feedstuff are standard variables from Heckscher-Ohlin type models of trade and firm location (see e.g. Roe, Irwin and Sharp 2000; Isik, 2004, Copeland and Taylor 2004) while the last pair, the one related to market potential is emphasised by NEG ${ }^{8}$ (see e.g. Krugman and Venables 1995; Roe, Irwin and Sharp 2000; Gaigné et al. 2012). The HO predicts that sectors that use a factor of production intensively will tend to locate in regions which are rich in that factor whereas NEG predicts that the attraction of a region's market potential is greater the more a sector sells to or buys inputs from other sectors. Therefore, the coefficients of the interaction variables $\beta$ are expected to be positive.

In Equation (4), $\theta$ and $\delta$ are vectors of respectively region and sector fixed effects, $\tau$ is a vector of time fixed effects and $\varepsilon$ is a vector of the error terms. The region fixed effects absorb the effects of any unobserved regional characteristics that affect all sectors such as geography, culture, regional policy of one sort or another and agglomeration economies. ${ }^{9}$ The sector fixed effects control for the effects of any unobserved sector characteristics such as the slaughter-intensity, differences in transportation cost and requirements for more specialized labor by animal category. ${ }^{10}$ The time fixed effects capture the impacts of factors such as prices and EU-wide polices that may affect all regions and sectors in a certain time period.

A more complete two-way fixed effects model would be one that has region*year and sector*year dummies (instead of region and sector dummies). However such a model could not be estimated because 
of multicollinearity which is not surprising considering the large number of dummy variables to be included: about $126 .{ }^{11} \mathrm{We}$ will explore two alternative estimators: one with standard errors that are robust (to arbitrary heteroscedasticity) and another that allows inter-group correlation between the error terms (specifically, allowing the error terms to be clustered by region-sector groups in order to capture persistence).

Ideally one would like to include the linear or constituent terms $x$ and $y$ in Equation 4. ${ }^{12}$ However, as the sector attribute variables are not time-varying, the linear terms cannot be included in our fixed effects model. Even in the absence of the region and sector fixed effects, inclusion of the linear terms would still cause perfect multicollinearity between some of the variables. Thus, our assumption in Equation 4 is that the linear terms are indeed absorbed by the region and sector fixed effects.

Given that our variables of region and sector characteristics are continuous, interpretation of the coefficients of the interaction variables, $\beta$ 's may not be straightforward. Consider, for example, the interpretation of the coefficient of environmental regulation laxity*pollution intensity. Do we take the causal story to be that environmental laxity modifies the effect of pollution intensity on the outcome variable (such as pig inventory) or pollution intensity modifies the effect of environmental laxity? As Brambor, Clark and Golder (2006, p. 72) point out "it is a feature of multiplicative interaction models that they are symmetric...and it is up to the analyst to determine which of these causal stories is theoretically more accurate." Obviously the substantive question in the context of the PHH is the effect of a region characteristic (such as environmental laxity) on the outcome variable for different values of the corresponding sector attribute (i.e. pollution intensity). To further ease interpretation of the estimated coefficients along the lines just discussed, we also report results from specifications where each regional characteristic is standardised by imposing zero mean and unit standard deviation, and also following Kee et al. (2010) each sector attribute variable is expressed in discrete terms such that it is equal to zero for sectors with a value below the mean, and one for sectors with a value above the average.

Thus, an estimated coefficient of, say for example, 0.05 for the interaction variable environmental laxity*pollution intensity can be interpreted as follows. A one unit increase (or a one standard deviation increase, in the case of standardized regional variables) in environmental laxity leads to a $5 \%$ increase in a region's share moderated by the pollution intensity of the sectors. ${ }^{13}$ Thus for the specification with the 
sector attribute variable expressed in discrete terms (zero for sectors with a value below the mean and one for sectors above the average), we can say that regions with lax environmental regulation have on average $5 \%$ higher share of pollution-intensive sectors than otherwise comparable regions and that for pollutionnon-intensive sectors there is no effect

\section{DATA AND VARIABLE CONSTRUCTION}

We use a three-way panel dataset with 43 NUTS-1 regions of six countries (Germany, Spain, The Netherlands, France, Denmark and Poland), three sectors (sows with piglets, weaners and finishing pigs) and three time periods (2003, 2004 and 2007). Detailed data description is provided in Appendix I, II and III. In this section we describe the definition of the individual country and sector variables used in the interaction model. The discussion here is limited to those relevant issues not contained in the Appendix or Tables 5 and 6 that present definition and summary statistics of the variables used in the econometric analysis. We also include here a further description of the main variables of interest in this paper, i.e. the environmental variables.

The restriction of our sample period to 2003, 2004 and 2007 is dictated by data availability of the environmental stringency variable. With respect to the econometric analysis, of the 43 regions, three German regions (Berlin, Bremen and Hamburg) are excluded from the analysis because of missing data on feedstuff for all the sample years and one region in France (Méditerranée) is dropped because of missing data on pig inventory. In addition feedstuff data are missing for 2007 for the 7 regions in Spain and the 4 regions in the Netherlands. As is common in the PHH literature our data on factor input intensity variables are time invariant. These data refer to the period around 2005.

\section{Dependent variable}

As the focus of our empirical study is on the intensity of a particular category of pig production, the outcome measure is the natural logarithm of a region's share of pig inventory by category (sector). The definition of a standard pig and the pig categories in Table 1 is common in EU countries but there can still be some differences, particularly in the weight of pigs at slaughter (Dourmad et al. 1999). ${ }^{14}$ We apply our empirical model for three animal categories: (i) sows (with piglets), (ii) pigs 20-50 kg (weaners), and (iii) fattening pigs ( $>50 \mathrm{~kg})$. 
For a robustness check, we will report results from two alternative outcome measures to head count of inventory. It can be argued that where pig production is concerned pollution is correlated with the amount of weight and value gained as smaller animal produce less manure than large ones. Thus the first alternative dependent variable is weight gained by each pig category. We used the pig inventory numbers together with data on weight gained per animal place to construct a measure of weight gained (in $\mathrm{kg}$ ). The second is value of production of each pig category. We used the data obtained for 'weight gained' and information on Euro/Tonne to construct a monetary value (in Euro). As in the case of our outcome measure of inventory, in both cases we work with shares in European total figures of a particular pig category. (See Appendix I for details on data for the three outcome measures).

\section{Region and sector characteristics}

The region and sector characteristics are summarised in Tables 5 and 6 . Availability of feeding-stuff is represented by the tons of harvest of all cereals excluding rice. The corresponding sector characteristic of feed intensity is captured by relative feedstuff consumption of each pig category. Labor availability is proxied by unemployment rate of the population aged 15 or over. The corresponding sector characteristic of labor intensity is represented by the average annual number of hours required for each sector. Domestic market potential is represented by Gross Domestic Product (GDP). The corresponding sector characteristic of scale economies is approximated by the number of farms in the largest size category by pig category. (See Appendix II for details on the construction of the sector variable).

$<$ Tables 5 and 6 about here $>$

Environmental regulation laxity can either mean weak rules or no effort to enforce, or lack of institutional or financial capabilities to enforce. Hence constructing an environmental stringency/laxity index based on a description of rules and regulations as such is not very meaningful. We used detailed information on costs to pig producers of regulation in different EU countries for several years constructed by the Agricultural Economics Research Institute in The Hague (see Appendix III). The Institute conducts research into the production costs of animal agriculture at regular intervals. We have obtained from this institute costs for pork in eurocents per kg slaughter weight (or kg live weight) for environmental reasons. 
These costs are taken as proxy for the stringency of national environmental stringency and are available for only the six countries in our sample for 2003, 2004 and 2007 (see Appendix III for further details).

To transform these abatement cost figures into a measure of environmental laxity we used the following: env. reg. laxity ${ }_{i}(t)=\left[c_{i}(t)-\max c_{i}(t)\right] /\left[\min c_{i}(t)-\max c_{i}(t)\right]$ where $\max c_{i}(t)$ and $\min$ $c_{i}(t)$ are the maximum and minimum environmental costs observed in the sample, respectively. The result is a measure of environmental laxity on the $[0,1]$ interval where 0 denotes the most strict regulations observed and 1 denotes no regulations at all (fully lax). ${ }^{15}$ This transformation is undertaken only just so we have a consistent expression for our variables of region characteristics, namely that a larger number represents greater abundance.

\section{Endogeneity of environmental regulation}

It is quite likely that our measure of environmental policy is endogenous, i.e. such a policy responds to the size and structure of the pig industry. Jurisdictions with large production of polluting sectors might raise their environmental standards or those with negligible amount of polluting activities may not enact stringent environmental policies (Millimet and Roy 2011; Gaigné et al. 2012). We use manufacturing output per worker, corruption and GDP per capita as instruments. Income is a commonly used instrumental variable in the literature and is suggested by standard theories of environmental regulation (see Copeland and Taylor 2004). Manufacturing output per worker is the equivalent of agricultural land per worker or number of tractors per worker which are used in Kellenberg's (2009) study of the location of manufacturing multinational affiliates. Following Kellenberg (2009) our argument is that manufacturing output per worker should reflect a country's relative technology level which determines the level of national production and is also positively correlated with environmental policy but should not directly affect pig production. Corruption is also a candidate instrumental variable based on political economy arguments on the role of quality of governance structure in the design and enforcement of environmental policy (see Fredriksson et al. 2003; Pellegrini and Gerlagh 2006). And corruption can be assumed to be exogenous to pig production. ${ }^{16}$ 
The corresponding sector attribute of pollution intensity is measured by the inclusive nitrogen loss of each pig category as calculated on the basis of the mean production level in practical pig production and the content in feed and retention according to the work by Jongbloed and Kemme (2005) (details in Appendix II). Note that the three instrumental variables are used to instrument for the environmental laxity variable and not for the environmental laxity and pollution intensity interaction variable.

\section{RESULTS AND DISCUSSION}

The main results of estimation of Equation 4 are presented in Table 7. All the regressions include region, sector and time-period fixed effects to soak up unobserved region-specific or sector-specific or time-specific excluded variables. ${ }^{17}$ The results in the first panel refer to regressions with continuous variables of the sector attributes. The results in the second panel are from regressions with standardized variables of region characteristics (i.e. normalized by imposing zero mean and unit standard deviation) and where the variables of our sector attributes are expressed in discrete terms of zero for values below the average and one for values above the average value of the respective attribute variable. The first column in each panel reports the OLS results and the second column in each panel presents results of the IV/2SLS counterpart.

$<$ Table 7 about here $>$

For the IV estimations we use manufacturing output per worker, corruption and GDP per capita as instruments. The standard specification tests (reported and explained at the bottom of Table 7) suggest that the identification strategy using these instruments works well. For both IV/2SLS specifications, the Anderson canonical correlation likelihood ratio test firmly rejects the null of model underidentication and the Craig-Donald $F$-test rejects the null of weak instruments. To test whether the instruments are valid, we performed the Hansen $J$-test for overidentifying restrictions. We find that the null of valid instruments is confirmed at any conventional level of significance and thus the models are supported. Finally, the Anderson-Rubin

Chi-Square-test rejects its null hypothesis and indicates that the endogenous regressors are relevant. 
The results are broadly similar across the specifications. The magnitudes of the coefficients in the model with standardized region variables interacting with discrete sector attributes are larger. The larger magnitude is attributable to the fact that what is measured is the outcome of a change in one standard deviation rather than a change in merely one unit of the region characteristic concerned. In none of the specifications is the labor interaction variable significant. It is hard to explain the consistent insignificance of this variable. It might have to do with the large intercorrelation between the labor and the environmental interaction terms ${ }^{18}$ or/and to our inability to capture differences in the quality of labor (specialized labor) required by different pig categories. The IV estimated coefficients of the environmental variable are consistently much larger than their OLS counterparts - a result in harmony with much of the evidence documented in the literature (Millimet and Roy 2011). ${ }^{19}$

As mentioned above, we have also explored two alternative outcome measures to our main measure of animal inventory: weight gained and value of production. Estimation results are reported in the Appendix (Tables A.2 and A.3, respectively). The main results are almost fully replicated. The only noticeable difference is a decline in the significance level in some of the endogeneity related tests.

The results reported in Table 7 are with standard errors that are robust (to arbitrary heteroscedasticity). An alternative estimator would be one that allows inter-group correlation between the error terms (specifically, allowing error terms to be clustered by region-sector groups in order to capture persistence). The results are reported in the Appendix (Table A.4). Of course the estimated coefficients are identical with those in the main specifications but there are some differences in significance levels. In one set of the results there is a slight decline in the significance level of the feedstuff interaction variable whereas in the other the market potential interaction variable becomes insignificant.

Overall the results are rather remarkable. It is to be noted that while there is an advantage of working with a fairly homogenous sample of countries, there is also a drawback. The advantage is that the possibility of omitted variable bias is minimized owing to the similarities of the regions. The drawback is the difficulty of finding significant results (for lack of sufficient variation), but if these are found as is the case here, they are more reliable. 
For interpretation of the actual magnitudes of the estimated coefficients, let's focus on the results of the two sets of results of the IV model in Table 7. Referring to the first, an increase in environmental laxity of a reduction in environmental cost by 0.1 Eurocent per $\mathrm{kg}$ of slaughtering animal would lead to a $9 \%$ increase in a region's share of pollution-intensive sectors moderated by this sector's actual pollution intensity ${ }^{20}$. The interpretation of the estimated coefficients is more straightforward for the set of results for the second IV specification. With reference to this specification, the one with discreet variables of sector attributes,. we can say that a one standard deviation increase in environmental laxity would lead to a $22 \%$ increase in a region's share of a pollution intensive sector and no change for a pollution non-intensive sector (see Footnote 13). Note that the increase relates to the regional (NUTS1) share of the total EU inventory of that animal sector, that is to $\mathrm{s}_{\mathrm{ik}}$. So the increase is in terms of animal numbers not farms. With the data employed in the estimation we can calculate the environmental impact associated with a $22 \%$ increase in one per cent of the EU inventory for the most polluting sector. This amounts to about 0.7 million $\mathrm{kg} \mathrm{N}$ per year. ${ }^{21}$ Using the inventory figures of Denmark as an example this would translate to an additional 6.3 million $\mathrm{kg} \mathrm{N}$ per year or an increase of $7.5 \%$ for this country. Similar interpretations hold for the other pairs of variables, mutatis mutandis.

More generally the positive estimated coefficients of $\beta$ means that a sector with relatively more (i.e. above average) intensive use of feedstuff is attracted to regions which are relatively more abundant in feedstuff. Likewise, a sector that is relatively more pollution intensive (growing pigs) would be drawn to regions which have relatively lax environmental standards (such as those in Poland). Finally, a sector with above-average scale economies tends to locate in regions that have relatively larger domestic market potential.

The picture that has emerged in our analysis might not fully come out if one were to rely on analyses of aggregate industry data - a common practice in the existing literature. Table 8 reports the results of regression for the aggregate pig sector. The dependent variable is a region's share of the pig industry as a whole and the independent variables are the regional characteristics as such (without interaction with the corresponding sector attributes). Both the OLS and the IV regressions include region and time-period fixed effects. Estimation results with our two alternative outcome measures 
of weight gained and value of production are reported respectively in Tables A.5 and A.6 in the Appendix. These results confirm the robustness of the main results.

$<$ Table 8 about here $>$

While the signs of the estimated coefficients are all as expected, no variable is consistently and robustly significant. Rather surprisingly, the hitherto troubling regional characteristic of labor turns out to be just significant in one specification. The coefficients of the rest of the variables are very far from being significant at any conventional level of significance. Specifically, the positive significant effects of environmental regulation laxity, market potential and feed variables estimated in the above sectoral (disaggregate) analysis are not born out in the aggregate data.

An opposing view could be that this set of results might not have much to do with the inadequacy of aggregate analysis per se - as we seem to be alluding to - but could arguably be due to a variety of factors such as econometric and data issues. However, given the fairly robust and plausible set of results of our sectoral (disaggregate) analysis we should be persuaded that the sectoral perspective must be a reasonable representation of the spatial patterns of the pig industry, at least in some contexts or datasets. Hence, allowing the data to speak alternative plausible stories might well be a worthwhile exercise.

Put together, the results of the sectoral and aggregate analyses suggest that while environmental regulation may not affect the overall inventory of pigs in a region it certainly does impact the composition of the industry: fattening pigs being relatively more pollution intensive tend to locate in regions where environmental standards are lax. This result is potentially interesting because the implication for pollution of the concentration of different sectors of the pig industry is different. Fattening period for example produces more waste per animal than the weaning period since that is the period of more weight gain. Furthermore, the intensification of live animal transportation associated with rising specialization might have an environmental implication of a different kind.

\section{CONCLUSION}

This paper documents the pattern of regional specialization in European pig industry and presents an econometrics analysis of the determinants of production location in the industry. Given the fact that this 
industry is increasingly subjected to stringent environmental regulations for its role in water and air pollution, a major focus of this paper is to evaluate the extent to which environmental policy is an influence in the location of production in the pig industry. Our analysis explicitly acknowledges the prevailing specialized operations within the pig industry. Thus, the main unit of analysis in our study is sector within the pig industry rather than the pig industry as a whole.

We employ a general empirical location model in which environmental regulation is one of several motives for location choices. We analyse data on the different sectors within the pig industry (i.e., sow (with piglet), weaner and fattening pig) in 43 NUTS-1 regions in six major pig industry European countries over the period 2003-2007.

The results suggest that while environmental regulation may not have a measurable effect on the location of the entire pig industry, it is indeed a strong influence on the sectoral composition of the industry. Regions with relatively lax environmental standards attract relatively highly polluting sectors of the pig industry. This is perhaps reassuring from a purely economic/employment point of view because it suggests that differential environmental standards would leave the regional distribution of the pig industry as a whole largely intact. From the point of the environment however there might be two reasons for consternation. The first is the emergence of pollution havens (i.e. hot spots of pig waste) as particularly polluting activities relocate to jurisdictions with lax environmental standards. In analogy with the well known carbon leakage effects one could call this the pig waste leakage effect. The second reason is that increased regional specialization in the pig industry - driven by differential environmental regulation would be accompanied by increased inter-regional transportation which has an environmental impact of a different kind. These conclusions have important implications for the further harmonisation of environmental regulation related to animal agriculture in the EU.

Further work could look into the transportation intensity of the animal categories with an aim to analyse the impact of proposed animal welfare regulations in individual countries that restrict the number of hours in transport. 


\section{Appendix I. Notes on data: outcome measures}

\section{Pig inventory}

Number of pigs of different category in different regions. The data source is Eurostat: Animal populations (December) [agr_r_animal]. EU25 data are missing for 2000, 2004, 2007 and 2008. We obtained estimates for these missing figures on the basis of a regression of EU25 figures over 2001-2003 on the average figures for the six countries in our sample. Data are also missing for France (and its regions) for 2000. We obtained an estimate for France as a whole in a similar fashion from a regression of the figures for France for 2001-2003 on the figures for EU 25. For French regions we used regressions of the figures for the respective region over 2001-2010 (excluding 2005-2006 for which data are missing for most regions) on the figures for France as a whole. Some regions have no pig inventories. We have included a very small number of 0.000001 to the inventory shares so that observations with zero inventories could also be used.

\section{Weight gained}

Weight (in $\mathrm{kg}$ ) gained by each pig category in different countries. We used the pig inventory numbers together with weight information by pig category. The latter information is mainly from Fowler (2007). For Poland we relied on Hoste and Puister (2009) and additional personal communation with Hoste. For sows and piglets the weight gained is the number of piglets weaned per sow per year and their weight at weaning. For pigs $20-50 \mathrm{~kg}$ this is transfer weight from rearing to finishing and the number of rounds per year. Similarly for fattening pigs $>50 \mathrm{~kg}$ the weight gained is based on end weight live at slaughter and rounds per year per pig place.

\section{Value of production}

Monetary value (Euro) of production (meat) for different pig category in different countries. We used the data obtained for 'weight gained' above and information on Euro/Tonne for pork from Eurostat. 


\section{Appendix II. Notes on data: sector characteristics}

\section{Pollution intensity}

Nitrogen losses in $\mathrm{kg} \mathrm{N}$ per yr per animal place for EU animal categories 400.407 and 411. The data source is Jongbloed en Kemme (2005).

\section{Feed intensity}

Relative feedstuff measure of consumption ( $\mathrm{kg}$ feed per animal place per $\mathrm{yr}$ ). The data is constructed on the basis of Jongbloed and Kemme (2005) who provide consumption in kgs feed on an annual basis for sow including piglets, weaner and growing pigs and data from Hoste and Bondt (2006) and Hoste and Puister (2009) for feed per kg gain at farm level for our six countries. We used the figures in Jongbloed and Kemme (2005) for the Netherlands and calculated the figures using the differences in feed per kg weight gain as given in the other two sources.

\section{Labor intensity}

Labor input use is constructed using:

(a) Total labor input per year (for the average sow + associated piglets, weaners and finishers) for each of the five countries (Hoste and Puister (2009). This is based on FADN data.

(b) Information on labor costs per year by pig category for the Netherlands (Publikatie Afsluitnormen).

(c) The combination of a and $\mathrm{b}$ then gives Labor Intensity (hours) by pig category as a constant by country for 2003, 2004. 2007.

\section{Scale economies (Farm size)}

Relative size of farms of different pig categories. The data source is Eurostat: Pigs: Number of farms and heads by size of farm (UAA) and size of breeding sow herd [ef_ls_gvsows]. The EUROSTAT publication by Marquer (2010) uses $>100$ sows and $>400$ fattening pigs to define large breeding and finishing farms, respectively. We follow Marquer's approach and adopt the following: (a) sow including piglets. sows 100 head or more, (b) growing pigs: pigs for fattening 400 head or more, and (c) weaners: same as for growing pigs. There is a slight problem as the 
Eurostat database provides data on farm size only for three categories as follows: piglets under $20 \mathrm{~kg}$; breading sows over $50 \mathrm{~kg}$; and others. This categorisation is not quite consistent with the one we are working with. So we take these three groupings to correspond respectively to weaners, sows including piglets and fattening pigs. We considered two alternatives for this variable: the number of large farms as such and the number of farms as a \% of the total number of farms with the specific type of pig. These two resulted in different rankings of the three pig categories. We decided to take the latter because what we would want is a measure that reflects optimal scale of operation which a mere number of farms of a certain size might not reveal (if farms of other sizes are also just as many).

\section{Appendix III. Notes on data: regional characteristics}

\section{Environmental Stringency Data}

The data on environmental stringency are from several publications by the Dutch Agricultural Economics Research Institute. This Institute conducts research into the production costs of animal agriculture at regular interval (Bondt et al. 2000, 2001; 2004; Hoste and Bondt 2006; Hoste and Puister 2009). The EU countries included in each of these five studies are Netherlands, France, Denmark, Germany and Spain. Regulation is distinguished in five categories: environment, animal welfare, animal health, public health and spatial planning (zoning). For our purpose we focus on only the environmental aspect of the regulation which is: additional costs for pork in eurocents per kg slaughter weight (or kg live weight) and is given for each of the five countries for 2003, 2004 and 2007. For Poland these costs are assumed to be zero for each of these years as this country joined the EU only in 2004.

\section{Land use}

Total land area. The data source is Eurostat: Land use [agr_r_landuse]. In order to make this data series compatible with the rest of the data we have added rows DEE0 (a region in Germany), ES63 and ES64 (regions in Spain) with no figures for land use, and deleted rows DEE1-DEE3 (regions of Germany). There are quite a few missing data for some regions and we have completed the series by a simple extrapolation (for example, data for 2000 would be assumed to be the same as that of 2001) - as this is the sort of data that hardly changes over time. Since land use data for EU25 are missing, we have 
used the total land use of the six countries in our sample to obtain regional shares for the purpose of calculating our 'concentration index'.

\section{Feed availability}

Cereals (excluding rice). The data source is Eurostat: Areas harvested, yields, production [agr_r_crops]. In millions of tons. In order to make this data series compatible with the rest of the data we have added rows DEE0 (a region in Germany), ES63 and ES64 (regions in Spain) with no figures for feed, and deleted rows DEE1-DEE3 (regions of Germany).

\section{Labor availability}

Total unemployment, age 15 or over. The data source is Eurostat: Unemployment rates by sex and age, at NUTS levels 1, 2 and 3 (\%) [lfst_r_lfu3rt].

\section{Market potential}

Gross Domestic Product (GDP) in PPS (Purchasing Power Standard). The purchasing power standard (PPS) is the name given by Eurostat to the artificial currency unit in which the PPPs and real final expenditures for the EU 25 are expressed - namely, euros based on the EU 25. It is deflated by HICP $(2005=100)$ - from Annual Data (average index and rate of change) [prc_hicp_aind]. The data source is Eurostat: GDP and main components - Current prices [nama_gdp_c].

Instrumental variables

\section{Manufacturing output per capita}

Production value in manufacturing divided by number of persons employed. Source: Annual detailed enterprise statistics on manufacturing subsections DA-DE and total manufacturing (NACE Rev.1.1 D) [sbs_na_2a_dade].

\section{Corruption}

Corruption perception index. Source: http://transparency.org/policy_research/surveys_indices/cpi. This index gives scores which we subtracted from 10.5 to construct our index, thus Denmark with the highest score of 9.5 in 2003 will have an index of 1. 
GDP per capita

Gross domestic product at market prices in Purchasing Power Standard per inhabitant ('0000).

Source: Eurostat: (nama_inc_c). 


\section{References}

Abdalla, C.W., L. E. Lanyon and M.C. Hallberg. 1995. "What we know about historical trends in firm location decisions and regional shifts: Policy issues for an industrializing animal sector." American Journal of Agricultural Economics 77(5): 1229-1236.

Bondt, N., R. Hoste, J.A. Boone, J.H. Wisman and G.B.C. Backus. 2000. "Developments in the cost price of pig meat --Production costs in 1998 and as projected for 2003." LEI Wageningen UR, Report Report 2.00.11. http://www.lei.dlo.nl/publicaties/PDF/2000/2_xxx/2_00_11.pdf

Bondt, N., R. Hoste, J.A. Boone, J.H. Wisman and G.B.C. Backus. 2001. "Kostprijsontwikkeling varkensvlees -- Productiekosten in 1999 en verwachting voor 2004.'[Production cost development for pork - Production costs in 1999 and outlook for 2004] LEI Wageningen UR, Report 2.01.07. http://www.lei.dlo.nl/publicaties/PDF/2001/2_xxx/2_01_07.pdf

Bondt, N., R. Hoste, J.A. Boone, J.H. Wisman and G.B.C. Backus. 2004. "Kostprijsontwikkeling varkensvlees -- Productiekosten in 2000 en verwachting voor 2005.' [Production cost development for pork - Production costs in 2000 and outlook for 2005] LEI Wageningen UR, Report Report2.02.04, http://www.lei.dlo.nl/publicaties/PDF/2002/2_xxx/2_02_04.pdf.

Brambor, T., W. Clark and M. Golder. 2006. "Understanding Interaction Models: Improving Empirical Analyses." Political Analysis 14(1): 63-82.

COM 2007. Report from the Commission to the Council and the European Parliament on implementation of Council Directive 91/676/EEC concerning the protection of waters against pollution caused by nitrates from agricultural sources for the period 2000-2003. SEC(2007)339. Commission for the European Communities, Brussels

.Copeland, B. and M.S. Taylor. 2004. "Trade, Growth and the environment." Journal of Economic Literature 42(1): 7-71.

Crafts, N. and A. Mulatu. 2005. "What explains the location of industry in Britain, 1871-1931?," Journal of Economic Geography 5(4): 499-518.

De Clercq, P., Gertsis, A.C., Hofman, G., Neeteson, J.J., Sinabell, F. (Eds.). 2001. "Nutrient Management Legislation in European Countries", The Netherlands: Wageningen Pers. ISBN 9080653721

De Winter, M.A., G.M.L. Tacken and L.F. Puister-Jansen. 2008. "Concurrentie monitor levend vee [Competiveness monitor for live animals]. Report 2008-063, The Hague: Agricultural Economics Institute.

Dourmad, J.Y., N. Guingand, P. Latimier, and B. Seve. 1999. "Nitrogen and phosphorus consumption, utilisation and losses in pig production: France." Livestock Production Science 58(3): 1999-211.

Esty, D.C. and M. Porter. 2002. "Ranking national environmental regulation and performance: a leading indicator of future competitiveness?" In: The Global Competitiveness Report 2001-2002, Porter, M. Sachs J., Schwab K. (eds). Oxford University Press: New York. 78-100.

European Commission. 2002. "Implementation of Council Directive 91/676/EEC concerning the protection of waters against pollution caused by nitrates from agricultural sources." Luxembourg: Office for Official Publications of the European Communities.

Fowler, T. 2007 Pig Costs of Production in selected countries, ADHB Meat Services Milton Keynes, UK

Frederiksen, B.S. 1995. "National Responses to the EC Nitrate Policy." Journal of Environmental Planning and Management 38(2): 253-264.

Fredriksson, P.G., J.A List and D.L. Millimet (2003). "Bureaucratic Corruption, Environmental Policy and US FDI: Theory and Evidence" Journal of Public Economics 87(7-8): 1407-1430.

Gaigné, C., J. Le Gaillo, S. Larue and B. Schmitt. 2012. "Does Regulation of Manure Land Application Work Against Agglomeration Economies? Theory and Evidence from the French Hog Sector." American Journal of Agricultural Economics 94(1): 116-132.

Gerlagh, R. and N.A. Mathys. 2011. "Energy Abundance, Trade and Industry Location.” Working Papers 03. Fondazione Eni Enrico Mattei.

Herath, D., A. Weersink, and C. Carpentier. 2005a. "Spatial and Temporal Changes in the US Hog, Dairy, and Fed-Cattle Sectors, 1975-2000." Review of Agricultural Economics 27(1): 49-69.

Herath, D., A. Weersink and C. Carpentier. 2005b. "Spatial Dynamics of the Livestock Sector in the United States: Do Environmental Regulations Matter? Journal of Agricultural and Resource Economics 30(1): 45-68. 
Hoste, R. and N. Bondt. 2006. "Productiekosten van varkens." [Production cost for pigs] LEI Wageningen UR Report 2.06.01. Rapport 2008-082 http://www.lei.dlo.nl/publicaties/ PDF/2006/ 2_xxx/2_06_01.pdf

Hoste, R and L. Puister. 2009. "Productiekosten van varkens." [Production cost for pigs] LEI Wageningen UR Report 2008-082. http://www.lei.dlo.nl/publicaties/PDF/2008/2008-082.pdf

Innes, R. 2000. "The Economics of Livestock Waste and Its Regulation." American Journal of Agricultural Economics 82(1): 97-117.

Isik, M. 2004. "Environmental Regulation and the Spatial Structure of the U.S. Dairy Sector." American Journal of Agricultural Economics 86(4): 949-62.

Jacobsen, B., A., Abildtrup and J. Orum. 2005 "Reducing Nutrient Losses in Europe and Implications for Farming - in the Light of the Water Framework Directives." Conference Paper, International Farm Management Association. http://ageconsearch.umn.edu/handle/24229.

Jeppesen, T., J.A. List and H. Folmer. 2002. "Environmental Regulation and New Plant Location Decisions: Evidence from a Meta-Analysis." Journal of Regional Science 42(1): 19-49.

Jongbloed, A.W. and P.A. Kemme. 2005. "De forfaitaire excretie van stikstof en fosfor door varkens, kippen, kalkoenen, eenden, konijnen en pelsdieren" [Standardized nitrogen and phosphorus excretion for pigs, chickens, turkeys, ducks, rabbits and furred animals] Lelystad: Animal Sciences Group, Report 05/101077, 101 pp.

Jongeneel, R., F. Brouwer. M. Farmer, R. Müssner, K. de Roest, X. Poux, G. Fox, A. Meister, Z. Karaczun, J. Winsten and C. Ortéga. 2007. Compliance with mandatory standards in agriculture; A comparative approach of the EU vis-à-vis the United States, Canada and New Zealand Projectcode 20528. Report 6.07.21, LEI, The Hague http://www.lei.dlo.nl/publicaties/PDF/2007/6_xxx/6_07_21.pdf

Kamann, D-J.F. and D. Strijker. 1994. "Spatial differentiation in the organisation of the European pork market.” In: Van Dijk, J. and Florax, R. (eds) Industriepolitiek, regional clusters en de werking van markten, Proceedings of the Meeting of the Regional Science Association, Geopress, Groningen.

Kee, H.L., H. Ma and M. Mani. 2010. "The Effects of Domestic Climate Change Measures on International Competitiveness", The World Economy 33(6): 96-106.

Kellenberg, D.K. 2009. "An empirical investigation of the pollution haven effect with strategic environment and trade policy". Journal of International Economics 78(2): 242-255.

Kliebenstein, J. and J.D. Lawrence. 1995. Contracting and Vertical Coordination in the US Pork Industry. American Journal of Agricultural Economics 77(5): 1213-1218.

Klimont, Z. and C. Brink. 2004. "Modelling of emissions of air pollutants and greenhouse gasses from agricultural sources in Europe." IIASA IR 04-048, Institute for Applied Systems Analysis, Laxenburg, Austria, http://www.iiasa.ac.at/rains/reports/ir-04-048.pdf.

Krugman, P. 1991 Geography and Trade. MIT Press, Cambridge, Massachusetts.

Larue, S., J. Abildtrup and B. Schmitt. 2011. "Positive and negative agglomeration externalities: Arbitration in the pig sector." Spatial Economic Analysis 6(2): 167-181.

Lence, S. 2007. "The Transformation of Spain's Pork Sector: Can it Continue?" Choices 22: 25-30.

Levinson, A and M.S. Taylor. 2008. "Unmasking the pollution haven effect." International Economic Review 49(1): 223-254.

Marquer, P. 2010. "Pig farming in the EU, a changing sector." Eurostat: Statistics in Focus, Agriculture and Fisheries, 8.

Metcalfe, M. 2001. "U.S. Hog Production and the Influence of State Water Quality Regulation." Canadian Journal of Agricultural Economics 49(1): 37-52.

Midelfart-Knarvik, K.H., H.G. Overman, S.J. Redding, A.J. Venables. 2000. "The Location of European Industry", Economic Papers No. 142. European Commission, D-G for Economic and Financial Affairs, Brussels.

Millimet, D.L. and J. Roy. 2011. "Three New Empirical Tests of the Pollution Haven Hypothesis When Environmental Regulation is endogenous.” IZA Discussion Paper Series No. 5911.

Mulatu, A., R., Gerlagh, D. Rigby, and A. Wossink. 2010. "Environmental Regulation and Industry Location in Europe." Environmental \& Resource Economics 45(4): 459-479.

Naylor, R., H. Steinfeld, W. Falcon, J. Galloway, V. Smil, E. Bradford, J. Alder, and H. Mooney. 2005. "Losing the links between livestock and land." Science 3310(5754): 1621-1622. 
Nguyen, L., M. Nuijens, H. Everts, N. Salden and A. Beynen. 2003. "Mathematical relationships between the intake of n- 6 and n-3 polyunsaturated fatty acids and their contents in adipose tissue of growing pigs." Meat Science 65(4): 1399-1406.

OECD 2013. Compendium of Agri-environmental Indicators. OECD, Paris. doi:10.1787/9789264186217-en

Oenema, O. 2004. "Government policies and measures regulating nitrogen and phosphorus from animal manure in European agriculture." Journal of Animal Science 82(e Suppl.): E196-206.

Overman, H. G., S. Redding, and A. Venables. 2003."The economic geography of trade, production and income: a survey of empirics.” In: Choi, E. Kwan and Harrigan, James, (eds.) Handbook of international trade. Blackwell Publishing, Malden, Massachusetts, pp. 353-387.

Pellegrini, L. and R. Gerlagh. 2006. "Corruption and environmental policies: what are the implications for the enlarged EU?" European Environment 16(3):139-154.

Raspiller, S. and N. Riedinger. 2008. "Do Environmental Regulations Influence the Location of French Firms." Land Economics 84(3): 382-395.

Roe, B., E. Irwin, and J. Sharp. 2002. "Pigs in Space: Modelling the Spatial Structure of Hog Production in Traditional and Non-traditional Production Regions." American Journal of Agricultural Economics 84(2): 259-278.

Schleef, K.-H. and Kleinhans, W. 1997. "Nitrogen balances at regional level in the European Union', in: F. Brouwer and W. Kleinhans (Eds.): The Implementation of Nitrate Policies in Europe: Processes of Change in Environmental Policy and Agriculture," Kiel, Germany: Wissenschaftsverlag Vauk.

Sneeringer, S.E. 2009. "Effects of Environmental Regulation on Economic Activity and Pollution in Commercial Agriculture." The B.E. Journal of Economic Analysis \& Policy 9: Article 31.

Sneeringer, S.E. and N. Key. 2011. "Effects of Size-Based Environmental Regulations: Evidence of Regulatory Avoidance." American Journal of Agricultural Economics 93(4): 1189-1211.

Taylor, S. 2004. "Unbundling the pollution haven hypothesis." Adv. Econ. Anal. Pol. 4, Article 8.

Van der Straeten, B., Buysse, J., Nolte, S., Lauwers, L., Claeys, D. and Van Huylenbroeck, G. 2012. "The effect of EU derogation stategies on the compliance cost of the nitrate directive." Science of the Total Environment 421-422: 94-101.

Vukina, T. 2003. "The relationship between contracting and livestock waste pollution." Review of Agricultural Economics 25(1): 66-88.

Weersink, A. and C. Eveland, C. 2006. "The Siting of Livestock Facilities and Environmental Regulations." Canadian Journal of Agricultural Economics 54(1): 159-173. 
Table 1. Pig stocks in the European Union

\begin{tabular}{|c|c|c|c|c|c|}
\hline \multicolumn{6}{|c|}{ Total pig stocks in the member states (1000 heads) - December survey 2002} \\
\hline & \multirow{2}{*}{$\begin{array}{c}\text { Total } \\
\text { (1000 heads) }\end{array}$} & \multicolumn{4}{|c|}{ Composition in \% } \\
\hline & & $\begin{array}{l}\text { Breeding } \\
\text { sows }\end{array}$ & Piglets & $\begin{array}{l}\text { Pigs } 20-50 \text { kg } \\
\text { (weaners- } \\
\text { feeder pigs) }\end{array}$ & $\begin{array}{c}\text { Pigs for } \\
\text { fattening } \\
\text { (hogs) }\end{array}$ \\
\hline EU-15 & 121991 & 10 & 28 & 24 & 37 \\
\hline 10 New member states* & 32141 & 10 & 30 & 24 & 36 \\
\hline EU-25 & 154737 & 10 & 29 & 24 & 37 \\
\hline Belgium & 6735 & 10 & 27 & 22 & 41 \\
\hline Denmark & 12879 & 11 & 32 & 28 & 29 \\
\hline Germany & 26251 & 10 & 27 & 25 & 38 \\
\hline Greece & 903 & 15 & 29 & 23 & 32 \\
\hline Spain & 23518 & 11 & 26 & 22 & 40 \\
\hline France & 15271 & 9 & 28 & 25 & 38 \\
\hline Ireland & 1782 & 10 & 29 & 28 & 32 \\
\hline Italy & 9166 & 8 & 19 & 20 & 52 \\
\hline Luxembourg & 76 & 10 & 28 & 22 & 40 \\
\hline Netherlands & 11154 & 10 & 41 & 20 & 29 \\
\hline Austria & 3305 & 10 & 25 & 29 & 36 \\
\hline Portugal & 2344 & 13 & 29 & 25 & 32 \\
\hline Finland & 1423 & 13 & 27 & 21 & 38 \\
\hline Sweden & 1989 & 11 & 31 & 23 & 35 \\
\hline United Kingdom & 5330 & 11 & 26 & 27 & 36 \\
\hline Czechoslovakia & 3429 & 14 & 29 & 23 & 34 \\
\hline Cyprus & 491 & 11 & 34 & 22 & 32 \\
\hline Estonia & 340 & 11 & 31 & 24 & 33 \\
\hline Latvia & 453 & 11 & 22 & 21 & 46 \\
\hline Lituania & 1061 & 9 & 17 & 26 & 48 \\
\hline Hungary & 5082 & 10 & 24 & 22 & 44 \\
\hline Malta & 78 & 9 & 24 & 27 & 39 \\
\hline Poland & 18997 & 13 & 33 & 25 & 33 \\
\hline Slovenia & 1882 & 10 & 27 & 22 & 41 \\
\hline Slovakia & 1554 & 11 & 29 & 23 & 37 \\
\hline
\end{tabular}

* The 10 new member states joined the EU in May 2004 and include: the Czech Rep., Cyprus, Estonia, Latvia, Lithuania, Hungary, Malta, Poland, Slovenia, and Slovakia.

Source: EUROSTAT. 
Table 2. Pig stocks in NUTS 1 regions of EU six countries* (average over 2000-2010 in '000)

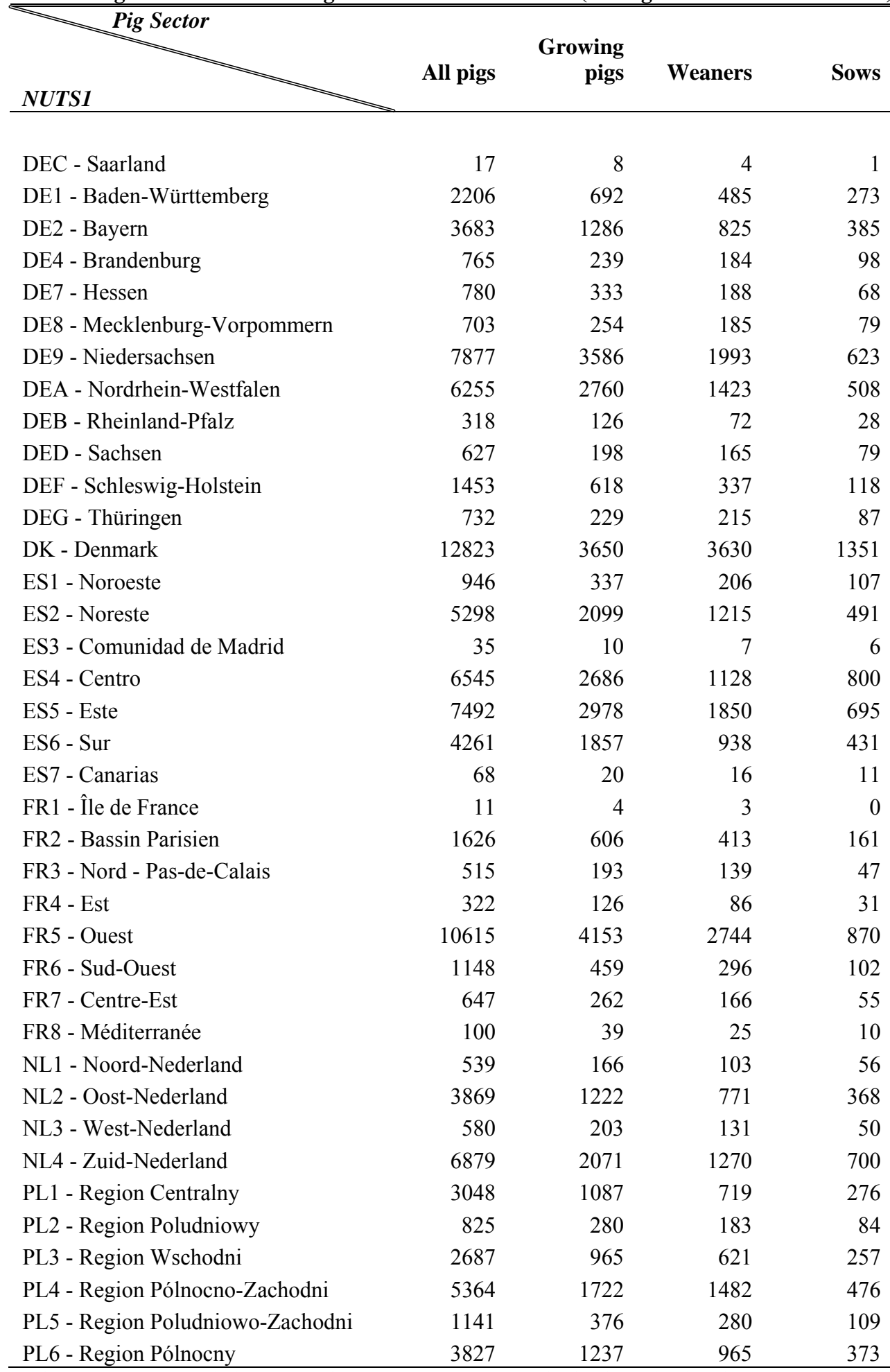

* The six countries include: Denmark, Germany, France, Netherlands, Poland and Spain. For five of the 43 NUTS-1 regions inventory data are missing for one or another of the sample years, hence excluded from the table. There are hardly inventory data for 2005 and 2006.

Source: Eurostat. 
Table 3. Krugman specialization index (Pigs inventory data)

\begin{tabular}{|c|c|c|c|c|c|c|c|}
\hline Year & 2000 & 2001 & 2002 & 2003 & 2004 & 2007 & 2008 \\
\hline DEC - Saarland & 0.389 & 0.449 & 0.452 & 0.470 & 0.434 & 0.412 & 0.467 \\
\hline DE1 - Baden-Württemberg & 0.236 & 0.238 & 0.235 & 0.208 & 0.249 & 0.252 & 0.298 \\
\hline DE2 - Bayern & 0.285 & 0.278 & 0.275 & 0.283 & 0.298 & 0.357 & 0.317 \\
\hline DE4 - Brandenburg & 0.242 & 0.214 & 0.228 & 0.217 & 0.212 & 0.223 & 0.283 \\
\hline DE7 - Hessen & 0.382 & 0.393 & 0.368 & 0.413 & 0.387 & 0.360 & 0.410 \\
\hline DE8 - Mecklenburg-Vorpommern & 0.258 & 0.275 & 0.294 & 0.251 & 0.261 & 0.270 & 0.283 \\
\hline DE9 - Niedersachsen & 0.396 & 0.414 & 0.372 & 0.420 & 0.389 & 0.417 & 0.492 \\
\hline DEA - Nordrhein-Westfalen & 0.404 & 0.441 & 0.400 & 0.451 & 0.430 & 0.373 & 0.472 \\
\hline DEB - Rheinland-Pfalz & 0.369 & 0.374 & 0.340 & 0.344 & 0.378 & 0.332 & 0.368 \\
\hline DED - Sachsen & 0.178 & 0.184 & 0.172 & 0.195 & 0.183 & 0.223 & 0.286 \\
\hline DEF - Schleswig-Holstein & 0.370 & 0.397 & 0.378 & 0.365 & 0.380 & 0.362 & 0.468 \\
\hline DEG - Thüringen & 0.282 & 0.251 & 0.257 & 0.240 & 0.221 & 0.245 & 0.234 \\
\hline DK - Denmark & 0.205 & 0.204 & 0.204 & 0.206 & 0.230 & 0.229 & 0.247 \\
\hline ES1 - Noroeste & 0.283 & 0.232 & 0.294 & 0.331 & 0.348 & 0.283 & 0.309 \\
\hline ES2 - Noreste & 0.292 & 0.475 & 0.432 & 0.473 & 0.456 & 0.310 & 0.345 \\
\hline ES3 - Comunidad de Madrid & 0.234 & 0.256 & 0.252 & 0.131 & 0.278 & 0.354 & 0.317 \\
\hline ES4 - Centro & 0.377 & 0.363 & 0.369 & 0.382 & 0.435 & 0.360 & 0.466 \\
\hline ES5 - Este & 0.419 & 0.326 & 0.322 & 0.317 & 0.356 & 0.342 & 0.379 \\
\hline ES6 - Sur & 0.464 & 0.403 & 0.398 & 0.356 & 0.424 & 0.379 & 0.446 \\
\hline ES7 - Canarias & 0.144 & 0.177 & 0.183 & 0.199 & 0.180 & 0.220 & 0.203 \\
\hline FR1 - Île de France & 0.341 & 0.380 & 0.381 & 0.298 & 0.313 & 0.297 & 0.485 \\
\hline FR2 - Bassin Parisien & 0.295 & 0.305 & 0.297 & 0.291 & 0.320 & 0.294 & 0.313 \\
\hline FR3 - Nord - Pas-de-Calais & 0.273 & 0.251 & 0.272 & 0.288 & 0.299 & 0.316 & 0.330 \\
\hline FR4 - Est & 0.307 & 0.370 & 0.346 & 0.320 & 0.353 & 0.300 & 0.328 \\
\hline FR5 - Ouest & 0.347 & 0.341 & 0.350 & 0.354 & 0.371 & 0.363 & 0.392 \\
\hline FR6 - Sud-Ouest & 0.324 & 0.327 & 0.339 & 0.350 & 0.371 & 0.330 & 0.346 \\
\hline FR7 - Centre-Est & 0.328 & 0.383 & 0.348 & 0.305 & 0.329 & 0.358 & 0.378 \\
\hline FR8 - Méditerranée & 0.294 & 0.333 & 0.328 & 0.356 & 0.359 & 0.374 & 0.306 \\
\hline NL1 - Noord-Nederland & 0.254 & 0.297 & 0.269 & 0.257 & 0.289 & 0.235 & 0.392 \\
\hline NL2 - Oost-Nederland & 0.259 & 0.335 & 0.281 & 0.272 & 0.295 & 0.251 & 0.407 \\
\hline NL3 - West-Nederland & 0.293 & 0.338 & 0.312 & 0.291 & 0.271 & 0.275 & 0.408 \\
\hline NL4 - Zuid-Nederland & 0.270 & 0.313 & 0.291 & 0.280 & 0.319 & 0.254 & 0.399 \\
\hline PL1 - Region Centralny & 0.337 & 0.281 & 0.295 & 0.328 & 0.328 & 0.293 & 0.345 \\
\hline PL2 - Region Poludniowy & 0.284 & 0.314 & 0.307 & 0.299 & 0.314 & 0.290 & 0.339 \\
\hline PL3 - Region Wschodni & 0.334 & 0.310 & 0.292 & 0.342 & 0.324 & 0.314 & 0.344 \\
\hline PL4 - Region Pólnocno-Zachodni & 0.274 & 0.256 & 0.264 & 0.259 & 0.288 & 0.274 & 0.266 \\
\hline PL5 - Region Poludniowo-Zachodni & 0.273 & 0.250 & 0.262 & 0.314 & 0.297 & 0.262 & 0.284 \\
\hline PL6 - Region Pólnocny & 0.268 & 0.245 & 0.255 & 0.274 & 0.292 & 0.246 & 0.288 \\
\hline Average & 0.304 & 0.315 & 0.308 & 0.309 & 0.323 & 0.306 & 0.354 \\
\hline Weighted average & 0.215 & 0.225 & 0.217 & 0.226 & 0.242 & 0.206 & 0.278 \\
\hline
\end{tabular}

See text for formula (Equation 1). For five of the 43 NUTS-1 regions inventory data are missing for one or another of the sample years, hence they are excluded from the table. There are hardly any inventory data for 2005 and 2006.

Source: Eurostat. 
Table 4. Index of concentration

\begin{tabular}{lccccccc}
\hline \hline & $\mathbf{2 0 0 0}$ & $\mathbf{2 0 0 1}$ & $\mathbf{2 0 0 2}$ & $\mathbf{2 0 0 3}$ & $\mathbf{2 0 0 4}$ & $\mathbf{2 0 0 7}$ & $\mathbf{2 0 0 8}$ \\
\hline $\begin{array}{l}\text { Sow (plus } \\
\text { piglet) }\end{array}$ & 0.680 & 0.660 & 0.649 & 0.659 & 0.791 & 0.663 & 0.679 \\
Weaner & 0.734 & 0.726 & 0.718 & 0.725 & 0.736 & 0.723 & 0.740 \\
Growing pig & 0.711 & 0.698 & 0.679 & 0.682 & 0.686 & 0.690 & 0.723 \\
& & & & & & & \\
\hline
\end{tabular}

See text for formula (Equation 3). For five of the 43 NUTS-1 regions inventory data are missing for one or another of the sample years, hence they are not included in the analysis. There are hardly any inventory data for 2005 and 2006.

Source Eurostat. 
Table 5. Regional characteristics

Variable

Definition
Data source

Availability of feedstuff Production of cereals (excluding rice) in millions of tons Eurostat

Eurostat

4.44

4.90

0.00

30.59

Availability of labor

Unemployment rates of the population aged 25-64

Eurostat

Domestic market potential GDP in Purchasing Power Standard (million millions) deflated by the price index HICP $(2005=100)$ for EU25

Environmental Regulation PORK additional costs due to policy measures

laxity

(Eurocents per kg slaughter weight): 1-(total cost/20)

Several publications by the

Dutch Agricultural Economics

Research Institute

10.48

$5.27 \quad 3.00$

24.10

1.87

3.64

0.00

1.00

Instrumental variables (for Environmental Regulation Laxity)

Corruption

Corruption perception index: $(10.5$ - corruption score in Transparency International the index)

Manufacturing output per Production value in manufacturing divided by number of Eurostat

worker persons employed.

GDP per capita

Per capita income in Purchasing Power Standard ('0000)

Eurostat
2.33
1.00

Detailed definitions of variables, notes on issues around missing data and data sources are given in Appendix II and III. Of the 43 regions, three German regions (Berlin, Bremen and Hamburg) are excluded from the analysis because of missing data on feedstuff and one region in France (Méditerranée) is dropped because of missing data on pig inventory. In addition feedstuff data are missing for 2007 for the 7 regions in Spain and the 4 regions in the Netherlands. 
Table 6. Sector characteristics

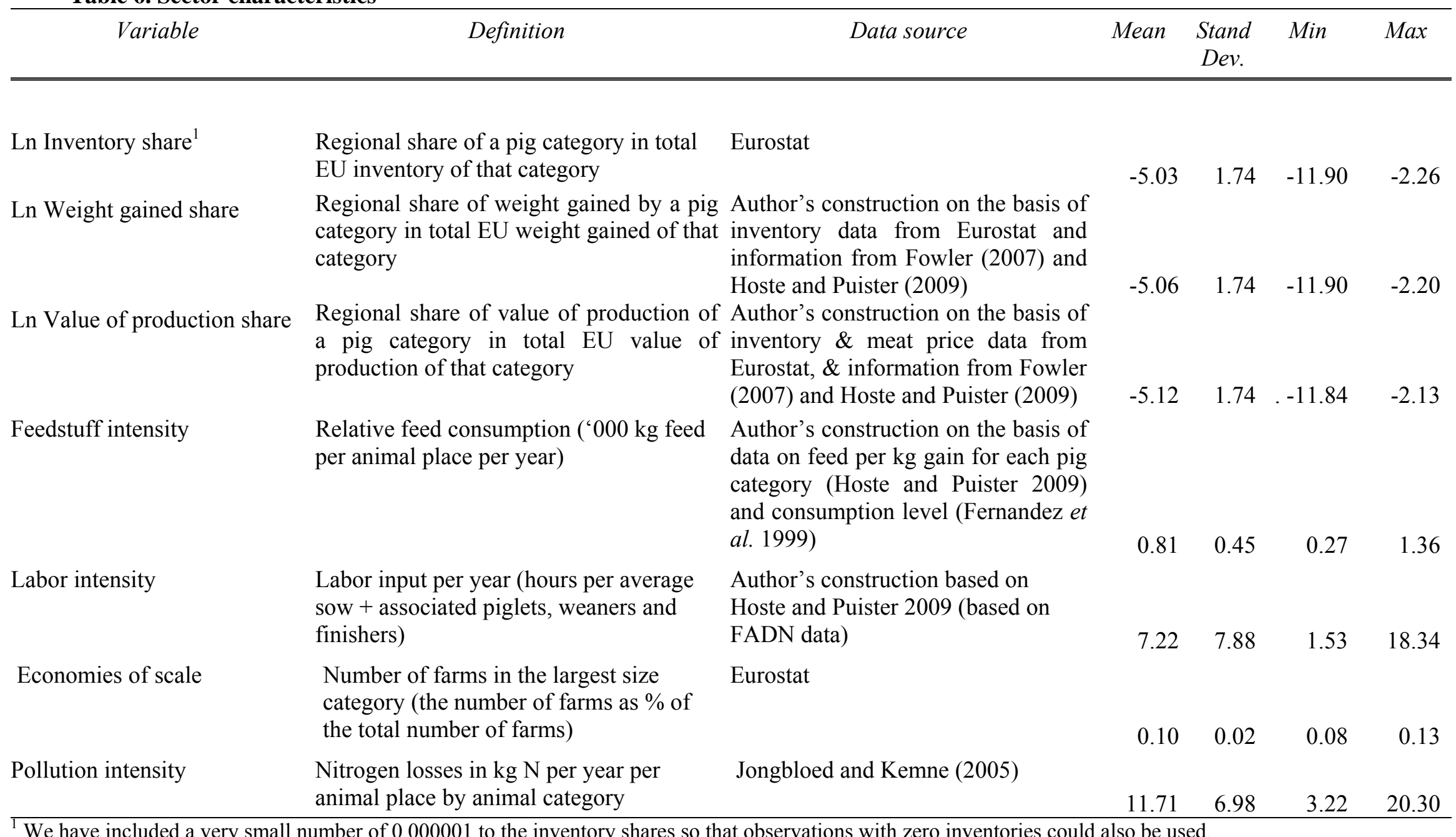

Detailed definitions of variables and data sources are given in Appendix I, II and III. 
Table 7. Regressions of regional shares of pig inventory (of different sectors)

\begin{tabular}{|c|c|c|c|c|}
\hline \multirow[b]{2}{*}{ Dependent variable: $\ln \left(s_{i k}\right)$} & \multicolumn{2}{|c|}{$\begin{array}{l}\text { With continuous } \\
\text { variables of sector } \\
\text { attributes }\end{array}$} & \multicolumn{2}{|c|}{$\begin{array}{l}\text { With standardized } \\
\text { region variables \& } \\
\text { discreet variables of } \\
\text { sector attributes }\end{array}$} \\
\hline & OLS & $\mathrm{IV} / 2 \mathrm{SLS}$ & OLS & IV/2SLS \\
\hline \multicolumn{5}{|l|}{$\begin{array}{l}\text { Interaction variables }\left(\beta^{j}\right) \text { and other } \\
\text { controls }\end{array}$} \\
\hline Feedstuff abundance * Feed intensity & $\begin{array}{l}0.0510 * * \\
(0.024)\end{array}$ & $\begin{array}{l}0.0509 * * \\
(0.023)\end{array}$ & $\begin{array}{l}0.2238 * * \\
(0.105)\end{array}$ & $\begin{array}{l}0.2264 * * \\
(0.098)\end{array}$ \\
\hline Labor abundance * Labor-intensity & $\begin{array}{l}0.0003 \\
(0.001)\end{array}$ & $\begin{array}{r}-0.0002 \\
(0.001)\end{array}$ & $\begin{array}{r}-0.0336 \\
(0.070)\end{array}$ & $\begin{array}{r}-0.0588 \\
(0.065)\end{array}$ \\
\hline Env. regulation laxity * Pollution intensity & $\begin{array}{l}0.0486^{* *} \\
(0.021)\end{array}$ & $\begin{array}{l}0.0942 * * \\
(0.036)\end{array}$ & $\begin{array}{l}0.1494 * * \\
(0.066)\end{array}$ & $\begin{array}{l}0.2186 * * \\
(0.092)\end{array}$ \\
\hline Market potential $*$ Scale economies & $\begin{array}{l}0.2421^{* *} \\
(0.109)\end{array}$ & $\begin{array}{l}0.2284 * * \\
(0.103)\end{array}$ & $\begin{array}{r}0.3610 \\
(0.238)\end{array}$ & $\begin{array}{l}0.3660 * \\
(0.220)\end{array}$ \\
\hline Period fixed effects & Yes & Yes & Yes & Yes \\
\hline Region fixed effects & Yes & Yes & Yes & Yes \\
\hline Sector fixed effects & Yes & Yes & Yes & Yes \\
\hline Underidentification & & 0.000 & & 0.000 \\
\hline Weak Identification & & 0.000 & & 0.000 \\
\hline Overidentification & & 0.193 & & 0.753 \\
\hline Joint Significance of Endog. Regressors & & 0.037 & & 0.065 \\
\hline$N$ & 318 & 318 & & 318 \\
\hline \multicolumn{5}{|c|}{$\begin{array}{l}\text { Notes: } \\
\text { Robust standard errors in parenthesis. *is significant at the } 10 \% \text { level. ** is significant at the } 5 \% \text { level. } \\
* * * \text { is significant at the } 1 \% \text { level. Excluded instruments are GDP per capita, manufacturing output per } \\
\text { capita and corruption. Underidentification reports the p-value of Anderson canonical correlations } \\
\text { likelihood ratio test of identification and rejection indicates that the model is identified. Weak } \\
\text { Identification reports the p-value of Cragg-Donald } F \text { test for the presence of weak instruments (meaning } \\
\text { that the model is only weakly identified). Overidentification reports the p-value of Hansen J statistic test } \\
\text { of instrument validity and rejection casts doubt on the validity. Joint Significance reports the p-value of } \\
\text { Anderson-Rubin Chi-square test of joint significance of endogenous regressors in the structural } \\
\text { equation. }\end{array}$} \\
\hline
\end{tabular}


Table 8. Regressions of aggregate share of pigs
Dependent variable: $\ln \left(s_{i}\right)$
OLS
IV/2SLS

Regional characteristics and other controls

\begin{tabular}{lcc}
\hline Feedstuff abundance & 0.1313 & 0.1098 \\
& $(0.131)$ & $(0.084)$ \\
Labor abundance & 0.0644 & $0.0694 *$ \\
& $(0.051)$ & $(0.042)$ \\
Env. regulation laxity & 0.2809 & 0.9996 \\
& $(0.380)$ & $(0.940)$ \\
Market potential & 0.1239 & 0.1351 \\
& $(0.172)$ & $(0.132)$ \\
Period fixed effects & Yes & Yes \\
Region fixed effects & Yes & Yes \\
\hline Underidentification & & 0.000 \\
Weak Identification & & 0.000 \\
Overidentification & & 0.153 \\
Joint Significance of Endog. Regressors & & 0.208 \\
$N$ & & \\
\hline \hline
\end{tabular}

Notes:

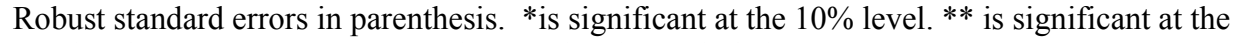
$5 \%$ level. $* * *$ is significant at the $1 \%$ level. Excluded instruments are GDP per capita, manufacturing output per capita and corruption. Underidentification reports the p-value of Anderson canonical correlations likelihood ratio test of identification and rejection indicates that the model is identified. Weak Identification reports the p-value of Cragg-Donald $F$ test for the presence of weak instruments (meaning that the model is only weakly identified). Overidentification reports the p-value of Hansen $\mathrm{J}$ statistic test of instrument validity and rejection casts doubt on the validity. Joint Significance reports the p-value of AndersonRubin Chi-square test of joint significance of endogenous regressors in the structural equation. 
Table A1. Overview of studies on the location of animal production

\begin{tabular}{|c|c|c|c|c|c|c|c|}
\hline Study & $\begin{array}{l}\text { Sector } \\
\text { analysed }\end{array}$ & $\begin{array}{l}\text { Geographical } \\
\text { focus \& period }\end{array}$ & $\begin{array}{l}\text { Empirical } \\
\text { model }\end{array}$ & Dependant variable & RHS variables & Environmental variable & $\begin{array}{l}\text { Results: pollution } \\
\text { haven hypothesis }\end{array}$ \\
\hline $\begin{array}{l}\text { Abdalla, Lanyon } \\
\text { and Hallberg, } \\
\text { (1995) }\end{array}$ & $\begin{array}{l}\text { Animal } \\
\text { sector }\end{array}$ & Whole USA & NA & NA & NA & & $\begin{array}{l}\text { Plant location and } \\
\text { market structure can be } \\
\text { a function of } \\
\text { environmental policy }\end{array}$ \\
\hline Metcalfe (2001) & Hog & $\begin{array}{l}18 \text { major hog } \\
\text { producing } \\
\text { states in USA; } \\
1986-1998\end{array}$ & $\begin{array}{l}\text { Supply } \\
\text { equation }\end{array}$ & $\begin{array}{l}\text { States' share of total } \\
\text { US hog inventory }\end{array}$ & $\begin{array}{l}\text { Market price of hogs; input } \\
\text { prices for feed and land; } \\
\text { environmental input price; \& } \\
\text { proxies for the costs of } \\
\text { transportation }\end{array}$ & $\begin{array}{l}\text { State Water Quality } \\
\text { Regulation }\end{array}$ & $\begin{array}{l}\text { Negative effect of } \\
\text { environmental } \\
\text { regulation on smaller } \\
\text { hog feeding operations }\end{array}$ \\
\hline $\begin{array}{l}\text { Roe, Irwin and } \\
\text { Sharp (2002) }\end{array}$ & Hog & $\begin{array}{l}15 \text { key hog } \\
\text { production } \\
\text { states in US; } \\
1992 \text { \& } 1997\end{array}$ & $\begin{array}{l}\text { Supply } \\
\text { equation with a } \\
\text { spatial lag } \\
\text { structure }\end{array}$ & $\begin{array}{l}\text { Hog inventory, by } \\
\text { county; the change } \\
\text { in inventories } \\
\text { between } 1992 \& \\
1997, \& \text { average } \\
\text { number of hogs per } \\
\text { farm }\end{array}$ & $\begin{array}{l}\text { Agglomeration proxies; urban } \\
\text { encroachment indicators; local } \\
\text { economic variables; } \\
\text { specialization indicators; market } \\
\text { access measures; regulatory } \\
\text { variables }\end{array}$ & $\begin{array}{l}\text { State-level stringency index } \\
\text { based on various states' } \\
\text { regulations }\end{array}$ & $\begin{array}{l}\text { Regulation lowers total } \\
\text { and per farm inventory } \\
\text { levels; but it may not } \\
\text { be uniformly repellent }\end{array}$ \\
\hline Isik (2004) & Dairy & $\begin{array}{l}\text { All continental } \\
\text { counties except } \\
\text { those with no } \\
\text { dairy farms in } \\
\text { the sample } \\
\text { period; } 1992 \& \\
1997\end{array}$ & $\begin{array}{l}\text { Supply } \\
\text { equation with a } \\
\text { spatial lag } \\
\text { structure }\end{array}$ & $\begin{array}{l}\text { Dairy inventories by } \\
\text { county; average } \\
\text { number of dairy } \\
\text { cows per farm, the } \\
\text { change in a county's } \\
\text { dairy inventories, } \\
\text { and the changes in } \\
\text { the share of a county } \\
\text { in the total cow } \\
\text { inventories between } \\
1992 \& 1997\end{array}$ & $\begin{array}{l}\text { Local economic conditions, } \\
\text { agglomeration economies, } \\
\text { climate conditions, and } \\
\text { socioeconomic factors }\end{array}$ & $\begin{array}{l}\text { State level stringency index } \\
\text { based the } 1998 \text { National } \\
\text { Survey of Animal } \\
\text { Confinement Policies }\end{array}$ & $\begin{array}{l}\text { Environmental } \\
\text { regulation affects dairy } \\
\text { inventories }\end{array}$ \\
\hline $\begin{array}{l}\text { Herath, Weersink, } \\
\text { and Carpentier } \\
\text { (2005a) }\end{array}$ & $\begin{array}{l}\text { Hog, } \\
\text { Dairy } \\
\text { cows and } \\
\text { fed-cattle }\end{array}$ & $\begin{array}{l}\text { eight major } \\
\text { Production } \\
\text { regions; 1975- } \\
2000\end{array}$ & $\begin{array}{l}\text { Entropy } \\
\text { Measures to } \\
\text { compare } \\
\text { concentrations } \\
\text { \& explain them }\end{array}$ & $\begin{array}{l}\text { Congraphical } \\
\text { Concentration: a } \\
\text { state's share of } \\
\text { livestock inventory }\end{array}$ & $\begin{array}{l}\text { Slaughtering/ processing } \\
\text { Capacity, population density and } \\
\text { environmental regulations }\end{array}$ & $\begin{array}{l}\text { Index; Green Index; and an } \\
\text { index based on the presence } \\
\text { or absence of sets of } \\
\text { livestock regulations as }\end{array}$ & Mixed \\
\hline
\end{tabular}




\begin{tabular}{|c|c|c|c|c|c|c|c|}
\hline Study & $\begin{array}{l}\text { Sector } \\
\text { analysed }\end{array}$ & $\begin{array}{l}\text { Geographical } \\
\text { focus \& period }\end{array}$ & $\begin{array}{l}\text { Empirical } \\
\text { model }\end{array}$ & Dependant variable & RHS variables & Environmental variable & $\begin{array}{l}\text { Results: pollution } \\
\text { haven hypothesis }\end{array}$ \\
\hline & & & & & & $\begin{array}{l}\text { reported in the State } \\
\text { Compendium. }\end{array}$ & \\
\hline $\begin{array}{l}\text { Herath, Weersink, } \\
\text { and Carpentier } \\
\text { (2005b) }\end{array}$ & $\begin{array}{l}\text { Hog, } \\
\text { dairy } \\
\text { cows and } \\
\text { fed-cattle }\end{array}$ & $\begin{array}{l}48 \text { contiguous } \\
\text { states; } 1976- \\
2000\end{array}$ & $\begin{array}{l}\text { Supply } \\
\text { equation }\end{array}$ & $\begin{array}{l}\text { A state's share of } \\
\text { national inventory } \\
\text { livestock }\end{array}$ & $\begin{array}{l}\text { Environmental regulation; } \\
\text { relative prices; livestock } \\
\text { infrastructure; general business } \\
\text { climate; and natural endowment }\end{array}$ & $\begin{array}{l}\text { State level stringency cu } \\
\text { index based on presence or } \\
\text { absence of seven } \\
\text { regulations }\end{array}$ & $\begin{array}{l}\text { Environmental } \\
\text { regulation affects the } \\
\text { hog and dairy sectors } \\
\text { but not the cattle-fed } \\
\text { sector }\end{array}$ \\
\hline $\begin{array}{l}\text { Weersink \& } \\
\text { Eveland (2006) }\end{array}$ & Hog & $\begin{array}{l}\text { municipalities } \\
\text { in } 8 \text { counties, } \\
\text { Canada; } 1996- \\
2001\end{array}$ & $\begin{array}{l}\text { Supply } \\
\text { equation }\end{array}$ & $\begin{array}{l}\text { Density of total barn } \\
\text { building permits, } \\
\text { new barn permits, \& } \\
\text { permits for hog } \\
\text { facilities }\end{array}$ & $\begin{array}{l}\text { Environmental regulations; } \\
\text { output \& input prices; business } \\
\text { climate; \& agglomeration } \\
\text { economies \& regional support } \\
\text { for farming }\end{array}$ & $\begin{array}{l}\text { local environmental } \\
\text { regulation: required manure } \\
\text { storage days; minimum } \\
\text { distance from waterway; } \\
\text { minimum lot size; nutrient } \\
\text { management plan } \\
\text { requirements; trigger for } \\
\text { expansion }\end{array}$ & $\begin{array}{l}\text { No measurable effect } \\
\text { of environmental } \\
\text { regulation }\end{array}$ \\
\hline Sneeringer (2009) & Hog & $\begin{array}{l}\text { North Carolina } \\
\text { at the county } \\
\text { level; } \\
\text { 1980-2005 }\end{array}$ & $\begin{array}{l}\text { Spline } \\
\text { regression } \\
\text { models of } \\
\text { supply and } \\
\text { emissions; } \\
\text { Differences in- } \\
\text { differences } \\
\text { approach }\end{array}$ & $\begin{array}{l}\text { Hog inventories by } \\
\text { county; SO2 and } \\
\text { PM10. }\end{array}$ & $\begin{array}{l}\text { Income, population, population } \\
\text { density, temperature, } \\
\text { precipitation, population over } 65 \\
\text { of age, unemployment rate, } \\
\text { poverty rate and number of } \\
\text { residential housing permit }\end{array}$ & $\begin{array}{l}\text { Exemption of swine } \\
\text { operations from county } \\
\text { zoning restrictions and } \\
\text { environmental penalties }\end{array}$ & $\begin{array}{l}\text { Lax (absence of) } \\
\text { environmental } \\
\text { regulation led to } \\
\text { increased presence of } \\
\text { the pork industry }\end{array}$ \\
\hline Sneeringer (2011) & Hog & $\begin{array}{l}\text { US states with } \\
100 \text { or more } \\
\text { 'finish' only } \\
\text { operations and } \\
\text { with the federal } \\
\text { regulatory } \\
\text { threshold in } \\
\text { place during } \\
1997,2002 \&\end{array}$ & $\begin{array}{l}\text { Regression } \\
\text { discontinuity } \\
\text { model }\end{array}$ & $\begin{array}{l}\text { Change in the } \\
\text { number of } \\
\text { operations by size } \\
\text { category over time }\end{array}$ & NA & $\begin{array}{l}\text { Regulatory threshold ( } 2,500 \\
\text { finishing hogs) used in state } \\
\text { and federal rules targeting } \\
\text { large scale operations }\end{array}$ & $\begin{array}{l}\text { Large \% of finish-only } \\
\text { hog farms operate at } \\
\text { size just below the } \\
\text { threshold - avoiding } \\
\text { regulation. This effect } \\
\text { increased between } \\
1997 \text { and } 2007\end{array}$ \\
\hline
\end{tabular}


Published in Land Economics, 2013

\begin{tabular}{|c|c|c|c|c|c|c|c|}
\hline Study & $\begin{array}{l}\text { Sector } \\
\text { analysed }\end{array}$ & $\begin{array}{l}\text { Geographical } \\
\text { focus \& period }\end{array}$ & $\begin{array}{l}\text { Empirical } \\
\text { model }\end{array}$ & Dependant variable & RHS variables & Environmental variable & $\begin{array}{l}\text { Results: pollution } \\
\text { haven hypothesis }\end{array}$ \\
\hline & & $\begin{array}{l}\text { 2007: Illinois, } \\
\text { Iowa, Kansas, } \\
\text { Missouri, } \\
\text { Minnesota, } \\
\text { Nebraska, } \\
\text { Ohio, South } \\
\text { Dakota \& } \\
\text { Wisconsin; }\end{array}$ & & & & & \\
\hline $\begin{array}{l}\text { Larue, Abildtrup } \\
\text { and Schmitt (2011) }\end{array}$ & Hog & $\begin{array}{l}\text { Denmark; } 1999 \\
\text { \& } 2004\end{array}$ & $\begin{array}{l}\text { Spatial lag } \\
\text { model }\end{array}$ & $\begin{array}{l}\text { Municipal pig } \\
\text { density }\end{array}$ & $\begin{array}{l}\text { Access to slaughterhouse, } \\
\text { feedstuff; population density and } \\
\text { distance to the German border }\end{array}$ & $\begin{array}{l}\text { Ratio of demand for land } \\
\text { for spreading of manure to } \\
\text { available land }\end{array}$ & Ambiguous \\
\hline $\begin{array}{l}\text { Gaigné et al. } \\
\text { (2012) }\end{array}$ & Hog & $\begin{array}{l}\text { French canton } \\
\text { (US equivalent } \\
\text { of county); } \\
1988 \& 2000\end{array}$ & $\begin{array}{l}\text { Spatial lag } \\
\text { model }\end{array}$ & $\begin{array}{l}\text { Hog production } \\
\text { density (number of } \\
\text { hogs per hectare) }\end{array}$ & $\begin{array}{l}\text { Access to feed (corn), access to } \\
\text { other cereals, access to slaughter } \\
\text { facilities, access to final } \\
\text { consumers, local degree of } \\
\text { urbanization, structure of farms } \\
\text { \& existence of inter-industry } \\
\text { externalities }\end{array}$ & $\begin{array}{l}\text { Availability of land for } \\
\text { manure spreading }\end{array}$ & $\begin{array}{l}\text { Land limitations due to } \\
\text { regulation on manure } \\
\text { application affect the } \\
\text { location of hog } \\
\text { production }\end{array}$ \\
\hline
\end{tabular}


Table A.2. Regressions of regional shares of pig weight gained (of different sectors)

\begin{tabular}{|c|c|c|c|c|}
\hline \multirow[b]{2}{*}{ Dependent variable: $\ln \left(s_{i k}\right)$} & \multicolumn{2}{|c|}{$\begin{array}{l}\text { With continuous } \\
\text { variables of sector } \\
\text { attributes }\end{array}$} & \multicolumn{2}{|c|}{$\begin{array}{l}\text { With standardized } \\
\text { region variables \& } \\
\text { discreet variables of } \\
\text { sector attributes }\end{array}$} \\
\hline & OLS & IV/2SLS & OLS & IV/2SLS \\
\hline \multicolumn{5}{|l|}{$\begin{array}{l}\text { Interaction variables }\left(\beta^{j}\right) \text { and other } \\
\text { controls }\end{array}$} \\
\hline Feedstuff abundance * Feed intensity & $\begin{array}{l}0.0549 * * \\
(0.024)\end{array}$ & $\begin{array}{l}0.0549 * * \\
(0.023)\end{array}$ & $\begin{array}{l}0.2414 * * \\
(0.105)\end{array}$ & $\begin{array}{l}0.2436 * * \\
(0.098)\end{array}$ \\
\hline Labor abundance * Labor-intensity & $\begin{array}{l}0.0000 \\
(0.001)\end{array}$ & $\begin{array}{r}-0.0005 \\
(0.001)\end{array}$ & $\begin{array}{l}-0.0593 \\
(0.071)\end{array}$ & $\begin{array}{r}-0.0798 \\
(0.064)\end{array}$ \\
\hline Env. regulation laxity * Pollution intensity & $\begin{array}{l}0.0406 * \\
(0.021)\end{array}$ & $\begin{array}{l}0.0876 * * \\
(0.036)\end{array}$ & $\begin{array}{r}0.0957 \\
(0.064)\end{array}$ & $\begin{array}{l}0.1521 * \\
(0.091)\end{array}$ \\
\hline Market potential $*$ Scale economies & $\begin{array}{l}0.2013 * \\
(0.110)\end{array}$ & $\begin{array}{l}0.1872 * \\
(0.104)\end{array}$ & $\begin{array}{l}0.4597 * \\
(0.236)\end{array}$ & $\begin{array}{l}0.4638 * * \\
(0.218)\end{array}$ \\
\hline Period fixed effects & Yes & Yes & Yes & Yes \\
\hline Region fixed effects & Yes & Yes & Yes & Yes \\
\hline Sector fixed effects & Yes & Yes & Yes & Yes \\
\hline Underidentification & & 0.000 & & 0.000 \\
\hline Weak Identification & & 0.000 & & 0.000 \\
\hline Overidentification & & 0.063 & & 0.449 \\
\hline Joint Significance of Endog. Regressors & & 0.036 & & 0.199 \\
\hline$N$ & 318 & 318 & & 318 \\
\hline \multicolumn{5}{|c|}{$\begin{array}{l}\text { Notes: } \\
\text { Robust standard errors in parenthesis. *is significant at the } 10 \% \text { level. ** is significant at the } 5 \% \text { level. } \\
* * * \text { is significant at the } 1 \% \text { level. Excluded instruments are GDP per capita, manufacturing output per } \\
\text { capita and corruption. Underidentification reports the p-value of Anderson canonical correlations } \\
\text { likelihood ratio test of identification and rejection indicates that the model is identified. Weak } \\
\text { Identification reports the p-value of Cragg-Donald } F \text { test for the presence of weak instruments (meaning } \\
\text { that the model is only weakly identified). Overidentification reports the p-value of Hansen J statistic test } \\
\text { of instrument validity and rejection casts doubt on the validity. Joint Significance reports the p-value of } \\
\text { Anderson-Rubin Chi-square test of joint significance of endogenous regressors in the structural } \\
\text { equation. }\end{array}$} \\
\hline
\end{tabular}


Table A.3. Regressions of regional shares of pig value of production (of different sectors)

\begin{tabular}{|c|c|c|c|c|}
\hline \multirow[b]{2}{*}{ Dependent variable: $\ln \left(s_{i k}\right)$} & \multicolumn{2}{|c|}{$\begin{array}{l}\text { With continuous } \\
\text { variables of sector } \\
\text { attributes }\end{array}$} & \multicolumn{2}{|c|}{$\begin{array}{l}\text { With standardized } \\
\text { region variables \& } \\
\text { discreet variables of } \\
\text { sector attributes }\end{array}$} \\
\hline & OLS & IV/2SLS & OLS & IV/2SLS \\
\hline \multicolumn{5}{|l|}{$\begin{array}{l}\text { Interaction variables }\left(\beta^{j}\right) \text { and other } \\
\text { controls }\end{array}$} \\
\hline Feedstuff abundance * Feed intensity & $\begin{array}{l}0.0540 * * \\
(0.024)\end{array}$ & $\begin{array}{l}0.0540 * * \\
(0.022)\end{array}$ & $\begin{array}{l}0.2380 * * \\
(0.103)\end{array}$ & $\begin{array}{l}0.2399 * * \\
(0.097)\end{array}$ \\
\hline Labor abundance * Labor-intensity & $\begin{array}{l}-0.0002 \\
(0.001)\end{array}$ & $\begin{array}{l}-0.0007 \\
(0.001)\end{array}$ & $\begin{array}{l}-0.0732 \\
(0.068)\end{array}$ & $\begin{array}{l}-0.0912 \\
(0.063)\end{array}$ \\
\hline Env. regulation laxity * Pollution intensity & $\begin{array}{l}0.0436 * * \\
(0.021)\end{array}$ & $\begin{array}{l}0.0868 * * \\
(0.035)\end{array}$ & $\begin{array}{l}0.1068 * \\
(0.063)\end{array}$ & $\begin{array}{l}0.1561 * \\
(0.090)\end{array}$ \\
\hline Market potential $*$ Scale economies & $\begin{array}{l}0.1947 * \\
(0.109)\end{array}$ & $\begin{array}{l}0.1817 * \\
(0.103)\end{array}$ & $\begin{array}{l}0.4627 * * \\
(0.232)\end{array}$ & $\begin{array}{l}0.4663 * * \\
(0.214)\end{array}$ \\
\hline Period fixed effects & Yes & Yes & Yes & Yes \\
\hline Region fixed effects & Yes & Yes & Yes & Yes \\
\hline Sector fixed effects & Yes & Yes & Yes & Yes \\
\hline Underidentification & & 0.000 & & 0.000 \\
\hline Weak Identification & & 0.000 & & 0.000 \\
\hline Overidentification & & 0.050 & & 0.401 \\
\hline Joint Significance of Endog. Regressors & & 0.029 & & 0.181 \\
\hline$N$ & 318 & 318 & & 318 \\
\hline
\end{tabular}

Notes:

Robust standard errors in parenthesis. *is significant at the $10 \%$ level. $* *$ is significant at the $5 \%$ level. *** is significant at the $1 \%$ level. Excluded instruments are GDP per capita, manufacturing output per capita and corruption. Underidentification reports the p-value of Anderson canonical correlations likelihood ratio test of identification and rejection indicates that the model is identified. Weak Identification reports the p-value of Cragg-Donald $F$ test for the presence of weak instruments (meaning that the model is only weakly identified). Overidentification reports the p-value of Hansen J statistic test of instrument validity and rejection casts doubt on the validity. Joint Significance reports the p-value of Anderson-Rubin Chi-square test of joint significance of endogenous regressors in the structural equation. 
Table A.4. Regression results of pig inventory with clustered error terms (clustered around Region-Sector)

\begin{tabular}{|c|c|c|c|c|}
\hline \multirow[b]{2}{*}{ Dependent variable: $\ln \left(s_{i k}\right)$} & \multicolumn{2}{|c|}{$\begin{array}{c}\text { With continuous } \\
\text { variables of sector } \\
\text { attributes }\end{array}$} & \multicolumn{2}{|c|}{$\begin{array}{l}\text { With standardized } \\
\text { region variables \& } \\
\text { discreet variables of } \\
\text { sector attributes }\end{array}$} \\
\hline & OLS & IV/2SLS & OLS & $\mathrm{IV} / 2 \mathrm{SLS}$ \\
\hline \multicolumn{5}{|l|}{$\begin{array}{l}\text { Interaction variables }\left(\beta^{j}\right) \text { and other } \\
\text { controls }\end{array}$} \\
\hline Feedstuff abundance $*$ Feed intensity & $\begin{array}{l}0.0510 \\
(0.036)\end{array}$ & $\begin{array}{l}0.0509 \\
(0.033)\end{array}$ & $\begin{array}{c}0.2238 \\
(0.146)\end{array}$ & $\begin{array}{l}0.2264 * \\
(0.137)\end{array}$ \\
\hline Labor abundance * Labor-intensity & $\begin{array}{l}0.0003 \\
(0.001)\end{array}$ & $\begin{array}{r}-0.0002 \\
(0.001)\end{array}$ & $\begin{array}{r}-0.0336 \\
(0.061)\end{array}$ & $\begin{array}{r}-0.0588 \\
(0.048)\end{array}$ \\
\hline Env. regulation laxity * Pollution intensity & $\begin{array}{l}0.0486 * * \\
(0.023)\end{array}$ & $\begin{array}{l}0.0942 * * \\
(0.045)\end{array}$ & $\begin{array}{l}0.1494 * * \\
(0.068)\end{array}$ & $\begin{array}{l}0.2186 * * \\
(0.108)\end{array}$ \\
\hline Market potential $*$ Scale economies & $\begin{array}{l}0.2421 * \\
(0.126)\end{array}$ & $\begin{array}{l}0.2284 * * \\
(0.110)\end{array}$ & $\begin{array}{c}0.3610 \\
(0.335)\end{array}$ & $\begin{array}{l}0.3660 \\
(0.308)\end{array}$ \\
\hline Period fixed effects & Yes & Yes & Yes & Yes \\
\hline Region fixed effects & Yes & Yes & Yes & Yes \\
\hline Sector fixed effects & Yes & Yes & Yes & Yes \\
\hline Underidentification & & 0.000 & & 0.000 \\
\hline Weak Identification & & 0.000 & & 0.000 \\
\hline Overidentification & & 0.293 & & 0.742 \\
\hline Joint Significance of Endog. Regressors & & 0.150 & & 0.062 \\
\hline$N$ & 318 & 318 & & 318 \\
\hline
\end{tabular}

Notes:

Robust standard errors in parenthesis. *is significant at the $10 \%$ level. ** is significant at the $5 \%$ level. *** is significant at the $1 \%$ level. Excluded instruments are GDP per capita, manufacturing output per capita and corruption. Underidentification reports the p-value of Anderson canonical correlations likelihood ratio test of identification and rejection indicates that the model is identified. Weak Identification reports the p-value of Cragg-Donald $F$ test for the presence of weak instruments (meaning that the model is only weakly identified). Overidentification reports the p-value of Hansen J statistic test of instrument validity and rejection casts doubt on the validity. Joint Significance reports the p-value of Anderson-Rubin Chi-square test of joint significance of endogenous regressors in the structural equation. 
Table A.5. Regressions of aggregate share of pigs: share of weight gained as LHS variable
Dependent variable: $\ln \left(s_{i}\right)$
OLS
$\mathrm{IV} / 2 \mathrm{SLS}$

Regional characteristics and other controls

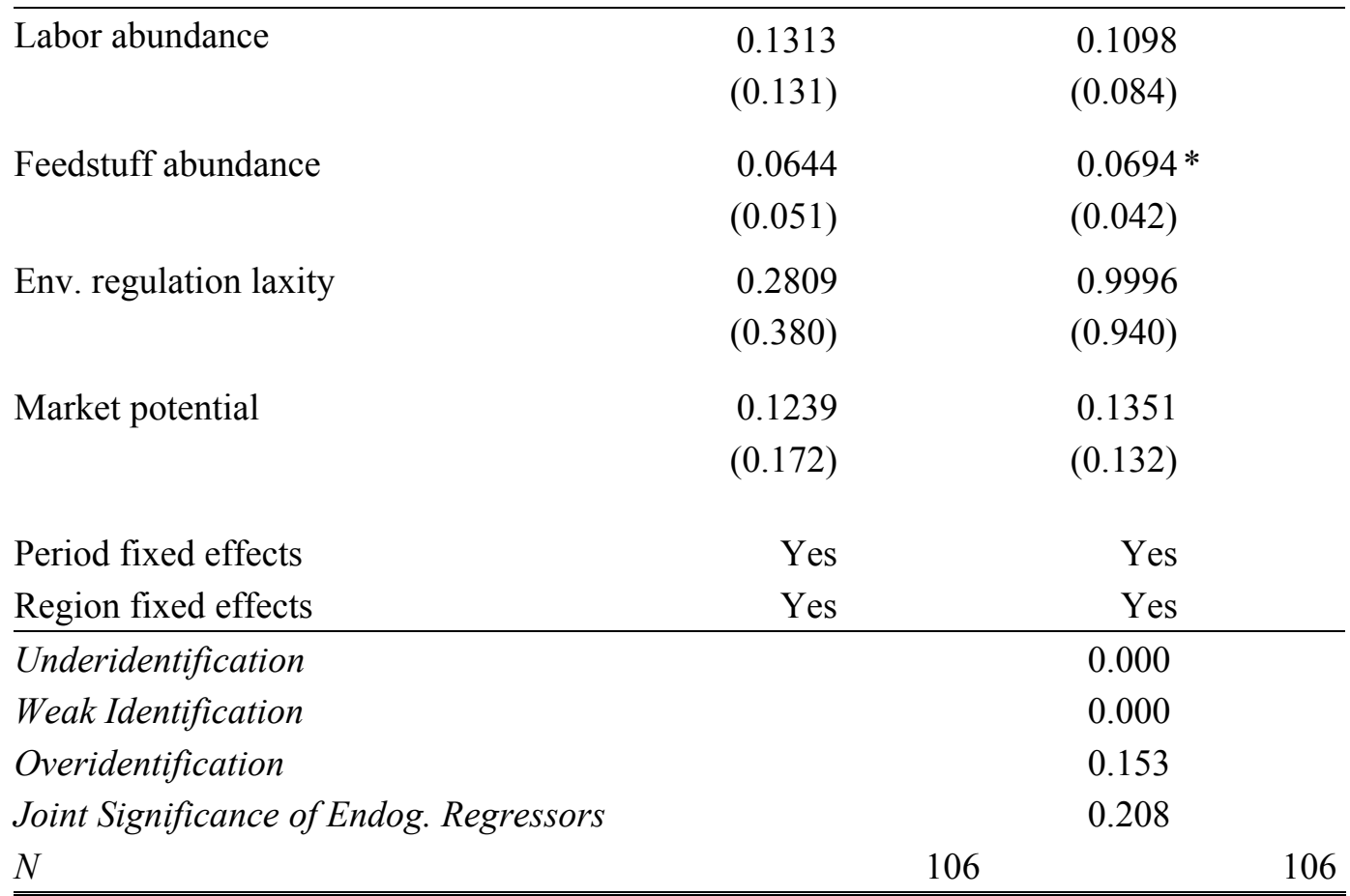

Notes:

Robust standard errors in parenthesis. *is significant at the $10 \%$ level. ** is significant at the $5 \%$ level. *** is significant at the $1 \%$ level. Excluded instruments are GDP per capita, manufacturing output per capita and corruption. Underidentification reports the p-value of Anderson canonical correlations likelihood ratio test of identification and rejection indicates that the model is identified. Weak Identification reports the p-value of Cragg-Donald $F$ test for the presence of weak instruments (meaning that the model is only weakly identified). Overidentification reports the p-value of Hansen $\mathbf{J}$ statistic test of instrument validity and rejection casts doubt on the validity. Joint Significance reports the p-value of Anderson-Rubin Chi-square test of joint significance of endogenous regressors in the structural equation. 
Table A.6. Regressions of aggregate share of pigs: share of value of production as LHS variable
Dependent variable: $\ln \left(s_{i}\right)$
OLS
IV/2SLS

Regional characteristics and other controls

\begin{tabular}{lcc}
\hline Labor abundance & 0.1308 & 0.1111 \\
& $(0.135)$ & $(0.087)$ \\
Feedstuff abundance & 0.0552 & 0.0597 \\
& $(0.053)$ & $(0.043)$ \\
Env. regulation laxity & 0.3334 & 0.9937 \\
& $(0.398)$ & $(0.963)$ \\
Market potential & 0.1297 & 0.1400 \\
& $(0.178)$ & $(0.137)$ \\
Period fixed effects & & \\
Region fixed effects & Yes & Yes \\
\hline Underidentification & & 0.000 \\
Weak Identification & & 0.000 \\
Overidentification & & 0.223 \\
Joint Significance of Endog. Regressors & & 0.271 \\
$N$ & & 106 \\
\hline
\end{tabular}

Notes:

Robust standard errors in parenthesis. *is significant at the $10 \%$ level. $* *$ is significant at the $5 \%$ level. *** is significant at the $1 \%$ level. Excluded instruments are GDP per capita, manufacturing output per capita and corruption. Underidentification reports the p-value of Anderson canonical correlations likelihood ratio test of identification and rejection indicates that the model is identified. Weak Identification reports the p-value of Cragg-Donald $F$ test for the presence of weak instruments (meaning that the model is only weakly identified). Overidentification reports the p-value of Hansen J statistic test of instrument validity and rejection casts doubt on the validity. Joint Significance reports the p-value of Anderson-Rubin Chi-square test of joint significance of endogenous regressors in the structural equation. 


\section{Footnotes}

${ }^{1}$ IThis is in line with the US where highly specialised systems make a distinction in three separate stages in swine production: farrows-to-wean farms that sell 10-15 pound weaned pigs; wean-to-feeder farms that buy the weaned pigs and sell them as 40-60 pound feeder pigs; and feeder-to-finish farms that finish the feeder pigs to about 260 pounds.

${ }^{2}$ For example, Jongbloed and Kemne (2005) give the following averages for annual N-excretions using data for the Netherlands: sow + piglets (till about 6 weeks of age) $20.3 \mathrm{kgN} / \mathrm{yr}$; weaners ( \pm 6 weeks till $25 \mathrm{~kg}$ ) $3.22 \mathrm{~kg}$ $\mathrm{N} / \mathrm{yr}$. and finishing pigs ( $\pm 25 \mathrm{~kg}$ till $\pm 110 \mathrm{~kg}) 11.6 \mathrm{~kg} \mathrm{~N} / \mathrm{yr}$. The associated $\mathrm{N}$-losses amount to $73 \%, 47 \%$ and $62 \%$ of $\mathrm{N}$-intake respectively.

${ }^{3}$ With an inventory of 153 million pigs on farms, the EU-25 ranks second in number of pigs in the world, after China (482 million) and ahead of the United States (60 million) (EUROSTAT; FAO Global Livestock Statistics, figures for 2003).

${ }^{4}$ EU's membership has grown with the enlargement from EU-15 to EU-25 in 2004 (Cyprus, Czech Republic, Estonia, Hungary, Latvia, Lithuania, Malta, Poland, Slovakia and Slovenia) and EU-27 in 2007 (Bulgaria and Romania).

${ }^{5}$ By contrast, there is a burgeoning research on PHH in the context of the manufacturing sector (see, for e.g., Raspiller and Riedinger 2008; and Copeland and Taylor 2004 for a review).

${ }^{6}$ An alternative specialization index would be a bi-regional one where each region is compared with each of the rest.

${ }^{7}$ See Midelfart-Knarvick et al. (2000, p .6).

${ }^{8}$ In some papers the New Economic Geography forces include the interaction between market potential and the share of intermediates in costs, the share of sales to industrial users, and scale economies. We have ignored the first two forces (the linkage effects) because they may not be applicable to the case at hand and if they were there is no reason to expect them to have differential effects on the three categories of the pig industry.

${ }^{9}$ The literature emphasises the importance of agglomeration/urbanisation economies (see e.g. Roe, Irwin and Sharp 2002, Weersink and Eveland 2006 and Larue, Abildtrup and Schmitt 2011). But there is no suggestion that such economies are sector-specific and hence covering them in region fixed effects might be plausible. We also ignore common region control variables such as a region's share of population, share of land area and climate as they are likely to be captured by region fixed effects. 
${ }^{10}$ We have also experimented with 'land share' (represented alternatively by 'total land area' or 'utilized agricultural area') as an explanatory variable but no sensible results were obtained.

${ }^{11}$ So in effect we are assuming that the unobserved region-specific and sector-sector-specific effects remain constant over time - hardly a heroic assumption given the time frame of our sample.

${ }^{12}$ Midelfart-Knarvik et al. (2000), Crafts and Mulatu (2004) and Mulatu et al. (2010) use cross-section data and hence include the linear terms of region characteristics and sector attributes. This in turn allows them to estimate the cut-off points. A cut-off point for a region characteristic refers to a neutral level of the characteristics such that a country with this level does not specifically attract sectors with high or low levels for the associated sector attribute. Similarly, a cut off point for a sector attribute refers to neutral level of the attribute such that a sector with this attribute level does not consider the associated region-characteristic in the selection of its location.

${ }^{13}$ For the simple regression model with dependent variable $\log (\mathrm{y})$ and independent variable $\mathrm{x}$ the interpretation of $\beta$ is as follows (see Wooldridge (2006, p.49): $\% \Delta y=(100 \beta) \% \Delta x$. However we have an interaction model and so in our case the interpretation becomes conditional on the moderating variable. Let the moderating variable, for example pollution intensity, be denoted by w. In our model the \%change in $s$ if environmental laxity changes is expressed by $100 * \beta \mathrm{w}$. It follows that the effect of a change in environmental laxity on $s$ is different by sector because this is conditional on the pollution intensity which is sector specific $(w)$. Note that for the specification with $w$ expressed in discrete terms (zero for sectors with a value below the mean and one for sectors above), the $\%$ change in $\mathrm{s}$ is $100 * \beta$ for a pollution intensive sector and zero for a pollution extensive sector, respectively.

${ }^{14}$ Traditionally European farmers produced pigs to three different weights to satisfy distinct market requirements: the bacon market (animals at $100 \mathrm{~kg}$ ), the processing market $(70 \mathrm{~kg}$ ) and the fresh pork market (about $55 \mathrm{~kg}$ ). In recent years improvements in management, nutrition and pig breeding have meant that animals can be grown onto a larger size without becoming fat, thus remaining suitable for the lower weight markets as well and most pigs are now slaughtered at the higher weight. Pigs finished for traditional products such as cured ham are fed a special diet and are slaughtered at for example $160 \mathrm{~kg}$.

${ }^{15}$ Comparison of this proxy measure of stringency with other more general and widely used stringency measures reveals the following. Our 2003 measure is positively correlated with the Environmental Sustainability Index (ESI) and Environmental Regulation Regime Index (ERRI). The correlation coefficients between our proxy and these measures 
are, respectively, $0.84,0.83$ and 0.86 . The ESI is constructed jointly by World Economic Forum, Yale Centre for Environmental Law and Policy, and Center for International Earth Science Information Network, Columbia University. The index refers to the year 2001 and is based on a total of 67 underlying variables (such as environmental regulatory stringency, environmental regulatory innovation and number of EIA guidelines). ERRI is reported in Esty and Porter (2002). It is based on a subset of the indexes that form the so called Environmental Sustainability Index (see the above footnote) supplemented by data from the World Economic Forum. The index refers to the year 2001 .

${ }^{16}$ We have also experimented with some other candidate instrumental variables such as land share, urbanisation and schooling. Using these variables as instruments does not work consistently and robustly but leave our main findings fairly intact.

${ }^{17}$ A Wald test on the hypothesis of the irrelevance of each of the three fixed effects is readily rejects the hypothesis.

${ }^{18}$ The correlation between the labor interaction and environmental interaction variable is 0.76 which is rather large whereas the correlation coefficients among the rest of the interaction variables are generally small (see the correlation matrix in the data section).

${ }^{19}$ Levinson and Taylor (2008) present a detailed discussion on statistical and theoretical sources of endogeneity of measures of environmental regulation and that, if unaccounted for, it can work against finding the pollution haven effect.

${ }^{20}$ Pollution intensity is based on Jongbloed and Kemne (2006). Sow plus piglets is most intensive with $20.3 \mathrm{~kg} \mathrm{~N}$ per pig place per year. One percent of the total number of sows in the EU equals about 155000 animals. The associated annual environmental impact (sows plus piglets ) of these 155000 animals is about 3.1 million $\mathrm{kg} \mathrm{N}$ per year. A $22 \%$ increase in inventory share would thus imply an additional 0.7 million $\mathrm{kg} \mathrm{N}$ per year. 